\title{
REVISION 2
}

2 Ferropyrosmalite-bearing fluid inclusions in the North Patagonian Andes

3 metasedimentary basement, Argentina: A record of regional metasomatism

Graciela Sosa ${ }^{1}$, Sebastián Oriolo ${ }^{2 *}$, Alfons Van den Kerkhof ${ }^{1}$, Pablo Diego González ${ }^{3}$, Ezequiel Olaizola ${ }^{4}$, Florencia Bechis ${ }^{4}$

${ }^{1}$ Geoscience Center, Georg-August-Universität Göttingen, Goldschmidtstrasse 3, D-37077

10 Göttingen, Germany.

${ }^{2}$ CONICET-Universidad de Buenos Aires. Instituto de Geociencias Básicas, Aplicadas y 12 Ambientales de Buenos Aires (IGEBA), Intendente Güiraldes 2160, C1428EHA Buenos 13 Aires, Argentina.

$14{ }^{3}$ Instituto de Investigación en Paleobiología y Geología (UNRN-CONICET), Avenida 15 Julio A. Roca 1242, R8332EXZ General Roca, Argentina.

${ }^{4}$ Instituto de Investigaciones en Diversidad Cultural y Procesos de Cambio, CONICETUniversidad Nacional de Río Negro, Bartolomé Mitre 630, R8400AHN San Carlos de Bariloche, Argentina.

*Corresponding author: seba.oriolo@gmail.com, soriolo@gl.fcen.uba.ar

\section{Abstract}

Quartz segregations in paragneisses from the Paleozoic basement of the North Patagonian Andes contain highly saline multiphase fluid inclusions with the rare daughter mineral ferropyrosmalite detected by Raman analysis, besides halite, sylvite, hematite and/or magnetite. During heating experiments, L-V homogenization occurs $\left(256-515{ }^{\circ} \mathrm{C}\right)$, followed by halite dissolution $\left(287-556^{\circ} \mathrm{C}\right)$ and the dissolution of ferropyrosmalite at 550 -

$27581{ }^{\circ} \mathrm{C}$. The latter phase transition triggers the growth of clino-amphibole crystals according to the following idealized reactions, written for potential end-members: 

similarities with chloro-hastingsite, as indicated by Raman spectroscopy. During the heating experiment, hematite (when present) transforms to magnetite by the uptake of $\mathrm{H}_{2}$, whereas inclusions without Fe-oxides contain traces of $\mathrm{H}_{2}$ after the reaction. This mineral transformation shows that ferropyrosmalite might result from the retrograde reequilibration

41 of amphibole with the brine, implying the uptake of $\mathrm{Fe}^{2+}, \mathrm{Cl}^{-}$and $\mathrm{H}_{2} \mathrm{O}$, and the enrichment

42 of $\mathrm{Ca}^{2+}$ in the brine. Pervasive fluid flow and fluid-assisted diffusion are recorded by 43 channelway microstructures, healed microfractures and dissolution-reprecipitation 44 phenomena, as demonstrated by cathodoluminescence microscopy. These alkali- and $45 \mathrm{FeCl}_{2}$-rich brines, derived from magmatic sources and of possible Mesozoic age, were 46 related to regional metasomatism, coeval with widespread granitoid activity.

47 Keywords: Ferropyrosmalite, ferro-actinolite, chloro-hastingsite, fluid inclusions, Raman 48 spectroscopy, fluid-assisted diffusion 


\section{Introduction}

Metasomatism is a solid-state metamorphic process that implies changes in the bulk composition, mineralogy and microstructures of rocks due to fluid-rock interaction (Zharikov et al. 2007; Harlov and Austrheim 2012). In the continental crust, metasomatic fluids are commonly derived from magmas and sedimentary brines, though they may have a metamorphic or mantle origin as well (Yardley and Bodnar 2014). Fluids may not only act as merely catalysts, but also cause compositional changes, introducing dramatic modifications to thermodynamic conditions (e.g., Putnis 2009; Putnis and Austrheim 2010; Putnis and John 2010). In addition, fluid-assisted diffusion can induce reequilibration through dissolution of parent phases and reprecipitation of products, producing mineral replacement. Coupled dissolution-reprecipitation is thus the main mechanism for mineral replacement reactions related to metasomatism (Putnis and Austrheim 2010; Ruiz-Agudo et al. 2014).

Fluid inclusions represent an irreplaceable tool for monitoring fluid flow associated with metasomatic processes (e.g., Kwak 1986; Harlov and Austrheim 2012; Raič et al. 2018). In high- to medium-grade metamorphic rocks, metasomatism commonly occurs during retrograde metamorphism and associated hydrothermal processes, triggering postentrapment reequilibration of fluid inclusions that may significantly replace the primary peak metamorphic assemblage (Vityk and Bodnar 1995; Touret 2001; van den Kerkhof et al. 2014; Bakker 2017). Such complex histories can only be disentangled by a careful examination of fluid inclusion microthermometric data in the light of microstructures based on both petrographic and cathodoluminescence (CL) observations, which can be further 
This is the peer-reviewed, final accepted version for American Mineralogist, published by the Mineralogical Society of America. The published version is subject to change. Cite as Authors (Year) Title. American Mineralogist, in press.

DOI: https://doi.org/10.2138/am-2021-7525. http://www.minsocam.org/

complemented by compositional data obtained by Raman spectroscopy, electron microprobe (EMP) or laser ablation - inductively coupled plasma - mass spectrometry (LA-ICP-MS) techniques (e.g., Touret 2001; van den Kerkhof and Hein 2001; Frezzotti et al. 2012; van den Kerkhof et al. 2014; Wagner et al. 2016).

Ferropyrosmalite, the Fe-rich end-member of the pyrosmalite series $\left[(\mathrm{Fe}, \mathrm{Mn})_{8} \mathrm{Si}_{6} \mathrm{O}_{15}(\mathrm{OH}, \mathrm{Cl})_{10}\right.$; Yang et al. 2012], is a relatively rare phyllosilicate that occurs in different metal-bearing ore deposits and is intimately associated with metasomatic processes, mostly attributed to the presence of hypersaline hydrothermal fluids ( $\mathrm{Li}$ and Naldrett 1993; Pan et al. 1993; Borrok et al. 1998; Tazava et al. 1999; Hanley and Mungall 2003; Cepedal et al. 2003; Koděra et al. 2003; Wanhainen et al. 2012). Though commonly associated with actinolite, sulphides, chlorides and iron oxides (Vaughan 1986; Pan et al. 1993; Dong and Pollard 1997; Koděra et al. 1998; Tazava et al. 1999; Hanley and Mungall 2003), robust constraints on ferropyrosmalite genetic conditions are still scarce. In this context, Koděra et al. (2003) proposed a retrograde reaction of clinopyroxene to ferropyrosmalite in saline fluid inclusions from altered granodiorites associated with a Feskarn deposit. Since the reaction between both minerals occurs at ca. $450{ }^{\circ} \mathrm{C}$, clinopyroxene might have been originally present as a daughter mineral, but was subsequently replaced by ferropyrosmalite as part of a low-temperature equilibrium assemblage (Koděra et al. 2003).

The aim of this paper is thus to evaluate post-metamorphic metasomatic processes recorded by the Late Paleozoic metamorphic basement exposed in northwestern Patagonia, providing new insights into ferropyrosmalite genesis and equilibrium conditions. For this purpose, a detailed study was carried out in fluid inclusions from metamorphic quartz segregations of high- to medium-grade metasedimentary rocks, combining fluid inclusion 
This is the peer-reviewed, final accepted version for American Mineralogist, published by the Mineralogical Society of America. The published version is subject to change. Cite as Authors (Year) Title. American Mineralogist, in press.

DOI: https://doi.org/10.2138/am-2021-7525. http://www.minsocam.org/

98

99

100

101

102

103

104

105

106

107

108

109

110

111

112

113

114

115

116

117 metamorphism and deformation of the basement was indicated by Oriolo et al. (2019) 118 based on monazite EPMA Th-U-Pb ages of $171 \pm 9$ and $170 \pm 7$ Ma. In addition, scarce 119 Late Jurassic volcano-sedimentary rocks are also exposed (Giacosa et al. 2001). Cretaceous

petrography, cathodoluminescence, microthermometry and Raman spectroscopy. Results are finally discussed in the context of regional tectonometamorphic and magmatic processes.

rocks that comprise paragneisses and schists with subordinate intercalations of amphibolites, metarhyolites, felsic orthogneisses and foliated intrusions (Fig. 1; Dalla Salda et al. 1991; García-Sansegundo et al. 2011; Oriolo et al. 2019). Though classically attributed to the Colohuincul Complex (Dalla Salda et al. 1991), these rocks were recently redefined as part of the Bariloche Complex (Oriolo et al. 2019), mostly due to differences in the age of the protolith deposition and the timing and characteristics of metamorphism and deformation. Devonian to Carboniferous metamorphism and deformation are constrained by monazite EPMA Th-U-Pb ages of $391.7 \pm 4.0$ and $350.4 \pm 5.8 \mathrm{Ma}$ for migmatitic paragneisses near the Brazo Tronador (Martínez et al. 2012), and monazite EPMA Th-U-Pb ages of $299 \pm 8$ and $302 \pm 16$ Ma for garnet-bearing schists of the Challhuaco hill (Oriolo et al. 2019).

Jurassic granitoids intruding the basement yield zircon U-Pb SHRIMP crystallization ages of ca. 176-160 Ma (Castro et al. 2011a). Coeval low-grade 
This is the peer-reviewed, final accepted version for American Mineralogist, published by the Mineralogical Society of America. The published version is subject to change. Cite as Authors (Year) Title. American Mineralogist, in press.

DOI: https://doi.org/10.2138/am-2021-7525. http://www.minsocam.org/

120

121

122

123

124

125

126

127

128

129

130

131

132

133

134

135

136

137

138

139

140

141

granitoids may be present as well, as suggested by K-Ar and Rb-Sr ages of ca. 120-80 Ma

(González Díaz 1982 and references therein). Despite the fact that monazite EPMA Th-U-

$\mathrm{Pb}$ ages of $110 \pm 10$ and $80 \pm 20 \mathrm{Ma}$ recorded by basement rocks suggest the presence of

Cretaceous magmatism and associated hydrothermal processes, the interpretation of these ages is still unclear (Oriolo et al. 2019). Finally, Cenozoic volcano-sedimentary sequences and granites are exposed as well (González Díaz 1982; Rapela et al. 1988; Giacosa et al. 2001; Bechis et al. 2014).

\section{Materials and methods}

\section{Sampling and microstructural characterization}

Samples of quartz segregations were collected from paragneisses of the Bariloche Complex for fluid inclusion analysis. Quartz segregations are parallel to the ubiquitous $\mathrm{S}_{2}$ metamorphic foliation, which represents the axial plane foliation of tight to isoclinal $F_{2}$ folds (Fig. 2a; García-Sansegundo et al. 2009; Oriolo et al. 2019). Rootless hinges of $F_{2}$ folds are commonly defined by folded quartz segregations (Fig. 2b; Oriolo et al. 2019). Samples were collected from paragneisses exposed at the western margin of the Jakob lake (sample BA 6-18; 41 ${ }^{\circ} 11^{\prime} 03.1^{\prime \prime} \mathrm{S}, 71^{\circ} 34^{\prime} 20.8^{\prime \prime} \mathrm{W}$ ) and the López hill (sample BA 28-18;

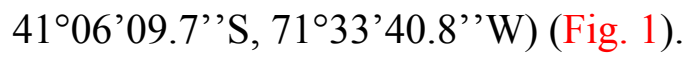

Due to the presence of relicts of folded $S_{1}$ in the microlithons of $S_{2}$, the latter is observed as a crenulation schistosity, comprising mica domains and microlithons of quartz and plagioclase (Oriolo et al. 2019). Plagioclase and garnet porphyroblasts are occasionally

present as well. Lepidoblastic muscovite and biotite exhibit shape-preferred orientation 
142 parallel to $\mathrm{S}_{1}$ and $\mathrm{S}_{2}$ planes, whereas quartz shows granoblastic microstructures. Fine-

143 grained chlorite \pm white mica \pm opaque minerals are typical retrograde minerals that

144 commonly exhibit shape-preferred orientation parallel to $\mathrm{S}_{2}$ planes (Fig. 2c), which is

145 locally affected by crenulation and $F_{3}$ microkinking (Oriolo et al. 2019). In addition, $S_{2}$ is

146 cross-cut by fine-grained aggregates of epidote, chlorite, white mica, titanite, apatite and

147 opaque phases (pyrite, chalcopyrite, magnetite and hematite), which overprint all 148 aforementioned microstructural features. In few cases, decussate actinolite is present as 149 well (Fig. 2d).

\section{Methodology}

Neuser CL microscope (Neuser et al. 1995) equipped with a Kappa DX 40C Peltier-cooled

$1551 \mathrm{~mA}$, corresponding to $20-40 \mu \mathrm{A} / \mathrm{mm}^{2}$ beam current density.

Phase transitions in fluid inclusions in quartz were investigated by using a

157 LINKAM THMS 600 heating-freezing stage cooled with liquid nitrogen. The stage was

158 calibrated by a set of synthetic fluid-inclusion standards. For temperatures around $-56.6{ }^{\circ} \mathrm{C}$

159 (the melting point of $\mathrm{CO}_{2}$ ) and around $0{ }^{\circ} \mathrm{C}$, the accuracy is better than $0.5{ }^{\circ} \mathrm{C}$, whereas for

160 temperatures between 200 and $600{ }^{\circ} \mathrm{C}$, the accuracy is better than $5^{\circ} \mathrm{C}$. Salinities of the

161 brines were calculated from ice melting temperatures using the equations of Bodnar (2003),

162 whereas the total salinities for oversaturated salt-bearing inclusions were estimated from

163 the model of Steele-MacInnis et al. (2011). 
This is the peer-reviewed, final accepted version for American Mineralogist, published by the Mineralogical Society of America. The published version is subject to change. Cite as Authors (Year) Title. American Mineralogist, in press. DOI: https://doi.org/10.2138/am-2021-7525. http://www.minsocam.org/

165 Jobin-Yvon HR-Raman spectrometer equipped with a $488 \mathrm{~nm}$ (blue) laser, attached to an

166 Olympus BX41 microscope. For quantitative measurements, spectra were acquired using a

167 100x objective between $100 \mathrm{~cm}^{-1}$ and $4000 \mathrm{~cm}^{-1}$, integrating 3 cycles of $30 \mathrm{~s}$ for each

168 measurement. Measurements were mostly carried out in unpolarized mode, though

169 polarized mode was also used in some cases, in order to check the effect of crystallographic

170 orientation. Gas components were detected based on the Raman vibration bands for $\mathrm{CO}_{2}$

171 (ca. 1388, $\left.1285 \mathrm{~cm}^{-1}\right), \mathrm{N}_{2}\left(\right.$ ca. $\left.2930 \mathrm{~cm}^{-1}\right), \mathrm{H}_{2} \mathrm{~S}\left(\right.$ ca. $\left.2611 \mathrm{~cm}^{-1}\right)$ and $\mathrm{H}_{2}\left(\right.$ ca. $\left.4156 \mathrm{~cm}^{-1}\right)$,

172 whereas gas ratios were determined with respect to the wavelength-dependent relative

173 Raman scattering cross-sections for a 488 nm laser unit (Burke 2001).

\section{Results}

\section{Cathodoluminescence of quartz}

178 rock alteration and paleo-porosity (e.g., Behr and Frentzel-Beyme 1987; Van den Kerkhof

179 and Hein 2001). Under CL, the quartz in the microlithons shows initial bright blue colors,

180 almost immediately changing to violet and red as a response to electron beam irradiation. A

181 number of microstructures visible only under CL are indicative of fluid-rock interaction,

182 including secondary zoning, grain boundary alteration, and channelway and cataclastic

183 healed microstructures (Fig. 3). In the studied samples, microstructures associated with

184 stages of high-temperature and low-temperature alteration were distinguished. 
This is the peer-reviewed, final accepted version for American Mineralogist, published by the Mineralogical Society of America. The published version is subject to change. Cite as Authors (Year) Title. American Mineralogist, in press. DOI: https://doi.org/10.2138/am-2021-7525. http://www.minsocam.org/

Quartz shows secondary zoning characterized by diffusive compositional variations within quartz grains. These microstructures are particularly common in the samples from the López hill, which record higher metamorphic temperatures. The altered quartz shows typically red CL, whereas the remaining relic patchy quartz shows bluish CL (1 in Fig. 3a). The microstructures typically show convex forms, indicative of grain boundary diffusion of trace elements (Van den Kerkhof et al. 2004).

Low-temperature metasomatism is characterized by cataclastic textures (i.e., healed microfractures and channelway microstructures) and grain boundary diffusion showing initial dark CL, changing to bright brown and red during the measurements. Quartz grains typically show reduced CL intensity along the boundaries ( 2 in Figs. 3a, b), suggesting trace element depletion along the rims during pervasive fluid flow. Cross-cutting relationships show that the oldest fluid pathways show blue CL, whereas younger microstructures show brown CL ( 3 and 4 in Fig. 3b). At the López hill, the blue CL in the channelways suggests the interaction with hot circulating fluids, whereas the latter microstructures are associated with alteration minerals like chlorite, epidote and apatite in veins and nests.

Quartz from the Jakob lake locality shows a dominance of low-temperature features. Quartz with extensive cataclastic microstructures exhibits unstable blue CL (5 in Fig. 3c), which grade to final bright red CL during electron beam irradiation. More complex microstructures (bright red CL) are related to subgrains, which are indicative of local recrystallization (6 in Fig. 3c). 
This is the peer-reviewed, final accepted version for American Mineralogist, published by the Mineralogical Society of America. The published version is subject to change. Cite as Authors (Year) Title. American Mineralogist, in press. DOI: https://doi.org/10.2138/am-2021-7525. http://www.minsocam.org/

\section{Fluid inclusions}

Fluid inclusions from the López hill location were studied in the mirrored fluid

209 plates of the CL sections, whereas those from the Jakob lake location were poorly

210 preserved and could not be measured by microthermometry. Based on fluid phase

211 petrography, early secondary multiphase inclusions and late secondary two-phase

212 inclusions were identified (Table 1).

Abundant multiphase highly saline fluid inclusions occur in clusters or are isolated,

214 and can be classified as early secondary, i.e., inclusions trapped during metasomatic

215 overprint and linked with the earliest fluid pathways in CL. They typically contain liquid

216 and vapor with a wide range of water volume fractions $(0.10-0.65)$ together with several

217 solid phases. The latter may take up to 70 vol. \% of the inclusions (Table 1). Halite and

218 sylvite are common daughter phases together with a number of Raman-active crystals.

219 Sylvite crystals, sometimes absent, are always smaller than halite. Rare early secondary

220 two-phase inclusions also occur, showing lower water volume fractions of 0.30-0.40 and

221 sometimes salt crystals (halite or halite + sylvite). The Raman-active minerals could be

222 identified as ferropyrosmalite and hematite (Fig. 4), or sometimes magnetite. The unusual

223 mineral ferropyrosmalite was optically observed as a transparent, colorless crystal with

224 occasional hexagonal morphology, which is in accordance with its trigonal symmetry (Fig.

225 4a). The bubble normally contains no detectable gas, but occasionally traces of $\mathrm{CO}_{2}$ occur,

226 as revealed by Raman analysis. Eutectic melting was normally observed between -58 and -

$22754{ }^{\circ} \mathrm{C}$, indicating the presence of significant $\mathrm{Ca}^{2+}\left( \pm \mathrm{Fe}^{2+}, \mathrm{Mg}^{2+}\right)$ concentrations in the brine.

228 After subsequent heating, the melting of ice between -46 and $-28{ }^{\circ} \mathrm{C}$, followed by the

229 melting of hydrohalite between -20 and $-12{ }^{\circ} \mathrm{C}$, was typically observed. During heating 
This is the peer-reviewed, final accepted version for American Mineralogist, published by the Mineralogical Society of America. The published version is subject to change. Cite as Authors (Year) Title. American Mineralogist, in press.

DOI: https://doi.org/10.2138/am-2021-7525. http://www.minsocam.org/

experiments, LV-homogenization of the early secondary multiphase inclusions took place between 256 and $515^{\circ} \mathrm{C}$ (Fig. 5a). Sylvite, if present, always dissolves before halite at ca. $190{ }^{\circ} \mathrm{C}$. However, $\mathrm{NaCl}$ must be dominant over $\mathrm{KCl}$, since hydrohalite can be clearly identified. Halite dissolves always after L-V homogenization between 287 and $556{ }^{\circ} \mathrm{C}$ and shortly after ferropyrosmalite dissolves. It is immediately followed by the simultaneous growth of a new greenish mineral between 550 and $581{ }^{\circ} \mathrm{C}$ (Fig. 5b). In a temperature range of ca. $10-20{ }^{\circ} \mathrm{C}$, both ferropyrosmalite and the new mineral coexist in the fluid inclusion. The new mineral often growths from the inclusion wall inwards and sometimes more than one crystal of the same species crystallizes within the same inclusion. This mineral was identified by Raman analysis as clino-amphibole (Fig. 4c). As a result of heating, several inclusions, notably those without an opaque phase, contain detectable amounts of $\mathrm{H}_{2}$, as revealed by the appearance of a Raman peak at $4156 \mathrm{~cm}^{-1}$ (Burke 2001). Phase transition temperatures and fluid properties are summarized in Table 1 and Figure 5.

Salinity calculations for the brine estimated from ice melting temperatures with the equation of Bodnar (2003) yielded 27-33 wt. \% $\mathrm{NaCl}$ eq. (Figs. 5c, 6). However, the eutectic temperatures of -58 to $-54{ }^{\circ} \mathrm{C}$, which mark the melting of antarcticite, indicate a $\mathrm{CaCl}_{2}$-dominated brine with additional components, most likely $\mathrm{NaCl}$ and $\mathrm{KCl}$, and probably more salts. As an approximation, brines are considered as ternary mixtures in the system $\mathrm{H}_{2} \mathrm{O}-\mathrm{CaCl}_{2}-\mathrm{NaCl}$. In that way, total salinity can be estimated from ice, hydrohalite and halite melting temperatures and the model of Steel-McInnes et al. (2011), yielding total salinity of $27-73$ wt. $\% \mathrm{NaCl}$ eq. (Figs. 5c, 6). The effect of additional $\mathrm{KCl}$ on the topology and isotherms in the ternary system, notably on the hydrohalite melting, is assumed to be minor, when considering the sum of dissolved alkali chlorides (Assarsson 1950). Ice melts 
This is the peer-reviewed, final accepted version for American Mineralogist, published by the Mineralogical Society of America. The published version is subject to change. Cite as Authors (Year) Title. American Mineralogist, in press. DOI: https://doi.org/10.2138/am-2021-7525. http://www.minsocam.org/

253 between -46 and $-28{ }^{\circ} \mathrm{C}$, and hydrohalite between -20 and $-12{ }^{\circ} \mathrm{C}$. For the oversaturated

254 multiphase inclusions, ice melting is often metastable, because halite is still present, 255 although salt hydrates and ice are the stable phases. However, the hydration reaction halite 256 to hydrohalite is very sluggish and does not occur here. On the other hand, L-V 257 homogenization and halite melting can be accurately reproduced in the heated inclusions, 258 returning the same phase transition temperatures documented before the reaction. In the early secondary inclusions, the extreme variation in salinity may either result 260 from the simultaneous entrapment of fluid and halite or from different portions of the 261 evolving magmatic fluid (Fig. 5b). Because of halite crystallization, this may also explain 262 the clear trend of brine compositions between high-salinity $\mathrm{NaCl}$-rich and low-salinity $263 \mathrm{CaCl}_{2}$-rich compositions (Fig. 6). The much lower solubility of $\mathrm{NaCl}$ compared to $\mathrm{CaCl}_{2}$ 264 ("salting out") results in the formation of halite crystals, which may become isolated in 265 modified inclusions. The rare and simpler early secondary inclusions without salts show the 266 same bulk compositions as the brine in the multiphase inclusions, pointing at incidental 267 fluid retrapping during cooling.

271 fractions between 0.70 and 0.87 , and vapor-rich inclusions with water volume fractions 272 between 0.05 and 0.30 (Table 1$)$. The salinities of both inclusion types are generally low ( < 2735 wt. $\% \mathrm{NaCl}$ ), as deduced from ice melting temperatures (from -3.2 to $1.5{ }^{\circ} \mathrm{C}$, for 274 metastable melting). The liquid-rich and vapor-rich inclusions occur in close association 275 within the same trails and were evidently trapped from immiscible fluids (heterogeneous 
trapping) during cooling. Eutectic melting, if observed, shows temperatures around $-21{ }^{\circ} \mathrm{C}$, pointing at the dominance of $\mathrm{NaCl}$ in solution. Raman analysis shows that some $\mathrm{V}-\mathrm{L}$ inclusions contain small amounts of $\mathrm{CO}_{2}$, sometimes with traces of $\mathrm{N}_{2}$ and/or $\mathrm{H}_{2} \mathrm{~S}$. However, the rare observation of $\mathrm{CO}_{2}$ or clathrate melting suggests very low density of the carbonic phase. This was confirmed by the properties of Raman spectra, pointing at densities $<0.4 \mathrm{~g} / \mathrm{cm}^{3}$, i.e., always below the critical density of $\mathrm{CO}_{2}$ (Fall et al. 2011), as the difference between the positions of the peaks of the Fermi diad is very small (between 102.4 and $103.5 \mathrm{~cm}^{-1}$ ). Partial homogenization of the carbonic phases to vapor was not observed. Total homogenization temperatures of the vapor-rich inclusions (to the vapor phase) fall in a relatively narrow range between 319 and $389{ }^{\circ} \mathrm{C}$. Homogenization temperatures of the liquid-rich inclusions (to the liquid phase between 254 and $384{ }^{\circ} \mathrm{C}$ ) fall in the same range, but are in part lower (Fig. 5a).

\section{Raman analysis of daughter phases}

Ferropyrosmalite in multiphase brine inclusions was irrevocably identified by Raman analysis (Fig. 7a) with characteristic peaks at $614,1024 \mathrm{~cm}^{-1}$, and in the O-H stretching region at 3550, 3577 and $3626 \mathrm{~cm}^{-1}$ (Dong and Pollard 1997; Koděra et al. 2003). Some smaller peaks at lower wavenumbers were found at 190 and $324 \mathrm{~cm}^{-1}$.

The opaque phase in the multiphase inclusions appeared to be either hematite (peaks at $223,290,403,610$ and $1305 \mathrm{~cm}^{-1}$ ), or sometimes magnetite (peaks at 537 and $667 \mathrm{~cm}^{-1}$ ). After heating of the inclusions, only magnetite could be detected when analyzing the opaque phases, suggesting hematite reduction. 
This is the peer-reviewed, final accepted version for American Mineralogist, published by the Mineralogical Society of America. The published version is subject to change. Cite as Authors (Year) Title. American Mineralogist, in press.

DOI: https://doi.org/10.2138/am-2021-7525. http://www.minsocam.org/

Heated brine inclusions contain clino-amphibole, as identified by Raman spectroscopy (Fig. 7b). Strong Raman peaks were found in the 640-665 and 990-1015 $\mathrm{cm}^{-1}$ ranges and relate to the amphibole chain structure (Lafuente et al. 2015). The peaks can be assigned to the symmetrical and asymmetrical stretching vibrations of Si-O-Si bridges, respectively. Smaller peaks at $250-400$ and $500-550 \mathrm{~cm}^{-1}$ are probably associated with the bending modes of the chains, as discussed by Apopei and Buzgari (2010). The same spectra could be well-reproduced for ca. 10-15 crystals found in the heated sample. The comparison with spectra of standard samples from the RRUFF database (Lafuente et al. 2015) shows similarities of the amphibole Raman spectra with ferro-actinolite (R060189) as well as with hastingsite (R070194). One prismatic crystal of amphibole was measured in polarized mode, parallel and perpendicular to the crystallographic c-axis (Fig. 7b).

Remarkable is the appearance of a clear Raman band at ca. $751-755 \mathrm{~cm}^{-1}$, which shows extreme intensity variation depending on the crystallographic orientation. In polarized light, the intensity is strongest for vibrations perpendicular to the crystallographic c-axis. The same peak was detected in reference samples of hastingsite (R070194) from the RRUFF database (Lafuente et al. 2015) and amphiboles with $\mathrm{Fe}^{3+}>{ }^{[6]} \mathrm{Al}^{3+}$ of andesites/dacites from the Taapaco volcano, Chile (Banaszak 2014). Koděra et al. (2003) noticed this peak for the new phase formed during heating and suggested the presence of another unidentified mineral phase. However, the clear correlation with the other peaks demonstrates that this Raman band must be part of the amphibole spectrum. In accordance with the hastingsite spectra and findings of Leissner et al. (2015) and Roesche (2018) for heated and oxidized amphiboles, it is assumed that the $751-755 \mathrm{~cm}^{-1}$ peak is associated with 
trivalent iron, formed by the oxidation of divalent iron and resulting in the shift of the symmetrical stretching mode to higher wavenumbers.

The three peaks assigned to $\mathrm{OH}^{-}$bonding, as recorded for ferropyrosmalite, disappeared after heating, or only one single peak in this range remained, which however does not coincide with any ferropyrosmalite peak. Several $\mathrm{OH}^{-}$bonding peaks for amphibole fall in the $3570-3770 \mathrm{~cm}^{-1}$ range (Lafuente et al. 2015), but in the heated inclusions only two peaks, a larger at ca. $3619 \mathrm{~cm}^{-1}$ and a smaller one at ca. $3653 \mathrm{~cm}^{-1}$, were detected for the majority of the ca. 10-15 analyzed inclusions. The low wavenumbers of these vibration modes can be explained by the substitution of Fe in the $\mathrm{M}(1) \mathrm{O}_{6}-\mathrm{M}(1) \mathrm{O}_{6^{-}}$ $\mathrm{M}(3) \mathrm{O}_{6}$ octahedra triplet sites and suggests a very high Fe/Mg ratio (Leissner et al. 2015; Roesche 2018). However, $\mathrm{OH}^{-}$vibrational peaks were strongly reduced and, in 3-5 cases, are even absent. The lack of these vibration modes can be possibly explained by the substitution of $\mathrm{OH}^{-}$by $\mathrm{Cl}^{-}$, as indicated by Fornero et al. (2008). It has been reported that Fe-rich amphiboles contain high concentrations of chlorine (e.g., Volfinger et al. 1985; Rebay et al. 2015), though chlorine incorporation can be also controlled by the substitution of $\mathrm{Al}^{3+}$ for $\mathrm{Si}^{4+}$ at tetrahedral sites and $\mathrm{K}^{+}$for $\mathrm{Na}^{+}$at $\mathrm{A}$ sites (Jenkins 2019). As the Raman spectra of the amphiboles in the fluid inclusions suggest very high Fe-contents, it is thus expected that chlorine concentration may be relatively high as well. Note that the amphibole forms in oversaturated brines after the dissolution of halite, often with a sylvite crystal present. Therefore, the unusual Raman spectra for the newly formed amphibole best fits compositions rich in iron and in a state of high oxidation, also with a possible contribution of potassium. 
This is the peer-reviewed, final accepted version for American Mineralogist, published by the Mineralogical Society of America. The published version is subject to change. Cite as Authors (Year) Title. American Mineralogist, in press. DOI: https://doi.org/10.2138/am-2021-7525. http://www.minsocam.org/

Finally, the bubbles of most natural, non-heated inclusions do not contain any Raman-active gas components. Some inclusions, however, contain $\mathrm{CO}_{2}$, sometimes with subordinated $\mathrm{N}_{2}$ and $\mathrm{H}_{2} \mathrm{~S}$, with composition ca. $\mathrm{CO}_{2}(83) \mathrm{N}_{2}(12) \mathrm{H}_{2} \mathrm{~S}(5)$ in the gas-rich late secondary inclusions. In samples which formed amphibole on heating but do not contain Fe-oxides, small amounts of $\mathrm{H}_{2}$ could be detected as well.

\section{Discussion}

\section{Ferropyrosmalite genesis and mineral-brine reactions}

The association of ferropyrosmalite, halite, sylvite and Fe-oxide in more or less the same volume ratios is typical for many of the studied fluid inclusions. Therefore, these minerals are considered as true daughter phases and not as captive minerals. Another argument is the absence of ferropyrosmalite as "solid inclusions" in quartz and exclusively found associated with high-salinity brines. At ca. $600{ }^{\circ} \mathrm{C}$ (the maximum temperature which can be reached with the heating stage), the clino-amphibole together with Fe-oxide, and often also sylvite, persist and could not be dissolved during experiments. This implies that inclusions must have formed at higher temperature, i.e., above the ferropyrosmaliteamphibole equilibrium temperature, thus implying that ferropyrosmalite formed from a retrograde reaction.

To our knowledge, the amphibole-forming reaction from ferropyrosmalite and brine in the heated fluid inclusions is reported here for the first time. It is assumed that amphibole must have been present in the inclusions at high temperatures and, consequently, ferropyrosmalite formed because of retrograde reactions of this mineral with the brine. The 
364

365

366

367

368

369

370

371 written as follows:

372

373

374

375 (aq.)

Ferropyrosmalite (2)

Ferropyrosmalite equilibrium temperature documented for the ferropyrosmalite to clino-amphibole reaction is $550-581{ }^{\circ} \mathrm{C}$, which is more than $100{ }^{\circ} \mathrm{C}$ higher than the temperature reported by Koděra et al. (2003) for the ferropyrosmalite-hedenbergite reaction. In a similar way to the ferropyrosmalite-clino-amphibole transformation, the latter implies the uptake of $\mathrm{FeCl}_{2}$ and $\mathrm{H}_{2} \mathrm{O}$, and the enrichment of $\mathrm{Ca}^{2+}$ in the brine (Koděra et al., 2003). Considering a pure $\mathrm{Fe}$ end-member for pyrosmalite, a pure ferro-actinolite amphibole, and that all released $\mathrm{O}_{2}$ converts to $\mathrm{OH}^{-}$, the equation for the ferropyrosmalite to amphibole transformation can be $4 \mathrm{Fe}_{8} \mathrm{Si}_{6} \mathrm{O}_{15}\left[(\mathrm{OH})_{6} \mathrm{Cl}_{4}\right]+6 \mathrm{Ca}^{2+}$ (aq.) $\leftrightarrow 3 \mathrm{Ca}_{2} \mathrm{Fe}_{5} \mathrm{Si}_{8} \mathrm{O}_{22}(\mathrm{OH})_{2}+17 \mathrm{Fe}^{2+}$ (aq.) $+16 \mathrm{Cl}^{-}$ $+$ $120 H^{-}$ $+$ $3 \mathrm{H}_{2}$ $\leftrightarrow$ Ferroactinolite

On the other hand, assuming a pure Fe end-member for pyrosmalite and Cl-rich hastingsite, the following reaction would be plausible:

$\mathrm{Fe}_{8} \mathrm{Si}_{6} \mathrm{O}_{15}\left[(\mathrm{OH})_{6} \mathrm{Cl}_{4}\right]+2 \mathrm{Ca}^{2+}$ (aq.) $+\mathrm{Fe}^{+3}$ (aq.) $+2 \mathrm{Al}^{3+}$ (aq.) $+\mathrm{Na}^{+}$(aq.) $+\mathrm{H}_{2} \mathrm{O} \leftrightarrow$ $\mathrm{NaCa}_{2}\left(\mathrm{Fe}^{2+}{ }_{4} \mathrm{Fe}^{3+}\right)\left(\mathrm{Al}_{2} \mathrm{Si}_{6}\right) \mathrm{O}_{22} \mathrm{Cl}_{2}+4 \mathrm{Fe}^{2+}$ (aq.) $+2 \mathrm{Cl}$ (aq.) $+4 \mathrm{H}_{2}$ $\leftrightarrow \quad$ Chloro-hastingsite

As previously exposed, the amphibole shows similarities with ferro-actinolite and hastingsite, indicating a Fe-rich amphibole, most likely in a high oxidation state. The presence of $\mathrm{Fe}^{3+}$ is problematic for ferro-actinolite, which only contains $\mathrm{Fe}^{2+}$, but could be satisfactorily explained by hastingsite. In that case, Raman evidence suggests a relatively 
This is the peer-reviewed, final accepted version for American Mineralogist, published by the Mineralogical Society of America. The published version is subject to change. Cite as Authors (Year) Title. American Mineralogist, in press. DOI: https://doi.org/10.2138/am-2021-7525. http://www.minsocam.org/

large $\mathrm{Cl}^{-} / \mathrm{OH}^{-}$ratio, pointing to a possible chloro-hastingsite composition, whereas the presence of $\mathrm{K}$ in A sites substituting $\mathrm{K}$ could also indicate potassic-chloro-hastingsite. The main limitation in the interpretation of hastingsite is the low solubility of $\mathrm{Al}^{3+}$, which is expected together with ferropyrosmalite after the retrograde reaction (2).

At the same time, magnetite probably formed as the result of hematite reduction, according to the following reaction (Matthews 1976):

$$
3 \mathrm{Fe}_{2} \mathrm{O}_{3}+\mathrm{H}_{2} \leftrightarrow 2 \mathrm{Fe}_{3} \mathrm{O}_{4}+\mathrm{H}_{2} \mathrm{O}
$$

The source for the hydrogen for the reaction likely results from the breakdown of ferropyrosmalite, according to the amphibole-forming reactions (1) and (2).

The reactions take place essentially in a closed system without addition or loss of any components from the host mineral. The presence of significant amounts of $\mathrm{Ca}( \pm \mathrm{Fe}$, $\pm \mathrm{Mg})$ in the associated fluids is based on the recognition of antarcticite $\left(\mathrm{CaCl}_{2} \cdot 6 \mathrm{H}_{2} \mathrm{O}\right)$ in the inclusions during cooling-heating runs. Antarcticite melting at eutectic temperatures of ca. $55^{\circ} \mathrm{C}$ was observed for the multiphase inclusions and point to $\mathrm{NaCl}-\mathrm{CaCl}_{2}$-bearing brines. Halite and sylvite reprecipitated on cooling and the newly formed phases seem to be stable at room temperature in most cases. The ferropyrosmalite-amphibole transformation appeared to be metastable over long periods, as the retrograde hydration-chlorination reaction to ferropyrosmalite has not been observed so far, not even after six hours of laser beam irradiation. However, Koděra et al. (2003) recorded the retrograde change from pyroxene to ferropyrosmalite, which was possibly stimulated by heating of the laser beam. Even though the retrograde reaction has not been observed under experimental conditions, it is assumed that it might have taken place in nature. 
This is the peer-reviewed, final accepted version for American Mineralogist, published by the Mineralogical Society of America. The published version is subject to change. Cite as Authors (Year) Title. American Mineralogist, in press. DOI: https://doi.org/10.2138/am-2021-7525. http://www.minsocam.org/

On the other hand, highest temperature conditions of $>581{ }^{\circ} \mathrm{C}$ recorded by fluid 409 inclusions suggest the interaction of metasedimentary rocks with hot circulating fluids 410 along channelways, presumably induced by post-peak metamorphic heating (e.g., van den 411 Kerkhof et al. 2004). Such relatively high-temperature conditions are further supported by 412 environmental conditions reported for the crystallization of Cl-rich amphiboles (e.g., 413 Giesting and Filiberto, 2016, and references therein), assumed to be a primary phase in the 414 studied fluid inclusions, and might be associated with regional low-pressure conditions, as 415 indicated by geological evidence. The recorded evolution towards lower temperature fluids 416 thus indicates a retrograde evolution from lower amphibolite to greenschist facies 417 conditions. On the other hand, high salinity, Ca-Fe-rich fluids associated with 418 ferropyrosmalite formation commonly have a magmatic source (e.g., Li and Naldrett 1993; 419 Borrok et al. 1998; Tazava et al. 1999; Hanley and Mungall 2003; Koděra et al. 2003). The 420 presence of magmatic sources for the studied fluids, possibly related to Mesozoic 421 tectonomagmatic events, are further supported by microstructural and geochronological 422 data of metamorphic rocks of the study area.

The existence of metasomatism coupled with regional retrograde conditions has

424 deep implications for the study of metamorphic processes. In the first place, it poses a 425 challenge for P-T thermodynamic modelling and construction of pseudosections, since the 426 assumption of a closed system and isochemical conditions is not valid, as the protolith 427 geochemical composition changes after interaction with the brine. On the other hand, no 428 evidence of metasomatic processes during retrograde metamorphism had been recorded in 429 the study area so far (García-Sansegundo et al. 2011; Martínez et al. 2012; Oriolo et al. 430 2019), whereas quartz segregations, which are structurally concordant with peak 
This is the peer-reviewed, final accepted version for American Mineralogist, published by the Mineralogical Society of America. The published version is subject to change. Cite as Authors (Year) Title. American Mineralogist, in press.

DOI: https://doi.org/10.2138/am-2021-7525. http://www.minsocam.org/

431

432

433

434

435

436

437

438

439

440

441

442

443

444

445

446

447

448

449

450

451

452

453

metamorphic basement fabrics (Figs. 2a, b), do not show any macro-/microstructural evidence of a post-metamorphic overprint. Only the combined use of CL, fluid inclusion and Raman analyses revealed the complex metasomatic evolution of the system, emphasizing the role of fluid-assisted dissolution-reprecipation processes.

\section{Regional implications}

The Paleozoic basement of the North Patagonian Andes is affected by low-grade metamorphism and deformation (Oriolo et al. 2019) coeval with the intrusion of Jurassic granitoids at ca. 176-160 Ma (Castro et al. 2011a). This is indicated by monazite EPMA Th-U-Pb ages of $171 \pm 9$ and $170 \pm 7 \mathrm{Ma}$, the latter recorded in the Jakob lake locality (Oriolo et al. 2019). On the other hand, minor monazite populations yielding ages of $110 \pm$ 10 and $80 \pm 20 \mathrm{Ma}$ were also obtained in the Jakob lake and Challhuaco hill, respectively (Fig. 1; Oriolo et al. 2019). The presence of Cretaceous granitoids in the region, however, is only poorly constrained by K-Ar and Rb-Sr ages of ca. 120-80 Ma (González Díaz 1982 and references therein).

Based on P-T conditions for the monazite-allanite equilibrium, Oriolo et al. (2019) suggested the presence of a regional high- to medium-temperature event under lowpressure conditions $(<6 \mathrm{kbar})$ to explain Mesozoic monazite ages. Since monazite (re)growth resulting from fluid-assisted metasomatic processes is well-documented (e.g., Budzyń et al. 2011; Harlov et al. 2011; Williams et al. 2011), Mesozoic monazite ages may thus constrain the timing of metasomatism recorded by fluid inclusions, further supported by the stability of monazite in the presence of $\mathrm{NaCl}$ brines (Budzyn et al. 2011). In addition, well-documented dissolution-reprecipitation microstructures in monazites of the 
This is the peer-reviewed, final accepted version for American Mineralogist, published by the Mineralogical Society of America. The published version is subject to change. Cite as Authors (Year) Title. American Mineralogist, in press. DOI: https://doi.org/10.2138/am-2021-7525. http://www.minsocam.org/

454

455

456

457

458

459

460

461

462

463

464

465

466

467

468

469

470

471

472

473

474

475

476

477

study area (Oriolo et al. 2019) could be explained by circulation of high-Ca-bearing brines, which promote monazite dissolution (Budzyń et al. 2011).

As further supported by regional evidence (e.g., Páez et al. 2010; Castro et al. 2011a, 2011b; Martínez Dopico et al. 2017; Suárez and González 2018), fluid flow and metasomatism recorded by fluid inclusions were thus likely related to a Jurassic tectonomagmatic event. However, they might also have been linked, at least partially, to Cretaceous and/or Cenozoic hydrothermal processes, which were reported for the study area as well (Giacosa et al. 2001). Though Cenozoic magmatism is well-documented by geochronological data and field relationships (e.g., Rapela et al. 1988; Bechis et al. 2014), the existence of Cretaceous magmatism is uncertain due to the lack of high-precision geochronological data. However, Cretaceous volcanism is exposed immediately northwest (Aragón et al. 2011) and significant Cretaceous exhumation associated with an early Andean tectonothermal event has been regionally recognized in the North Patagonian Andes (Orts et al. 2012; Oriolo et al. 2019; Olaizola et al. 2020).

Basement fabrics played a major role as first-order structural controls in the evolution of Mesozoic and Cenozoic magmatic and sedimentary processes in northern Patagonia (Renda et al. 2019). In the particular case of the study area, microstructural evidence of basement rocks suggests significant reactivation of metamorphic fabrics and deformation-assisted replacement reactions during retrograde metamorphism (Oriolo et al. 2019). The Paleozoic metamorphic foliation might thus represent an effective pathway allowing fluid circulation, which in turn promoted retrograde metamorphic reactions and reequilibration in an otherwise dry and thus less reactive crustal section (e.g., Jamtveit et al. 2000; Altree-Williams et al. 2015). In this context, the possible reactivation of metamorphic fabrics (Oriolo et al. 2019) might be crucial for generating secondary porosity 
478 due to generation of open spaces, where fluids could circulate and further increase porosity

479 by hydraulic fracturing and dissolution-reprecipitation, as supported by healed 480 microfractures and compositional changes revealed by CL data.

481

484

485

486

487

488

489

490

491

\section{Conclusions}

Clino-amphibole experimentally formed after heating in ferropyrosmalite-bearing fluid inclusions, suggesting that ferropyrosmalite was formed as a retrograde phase in fluid inclusions in the studied quartz crystals. The reaction implies the uptake of $\mathrm{Fe}^{2+}$ and $\mathrm{Cl}^{-}$, and the enrichment of $\mathrm{Ca}^{2+}$ in the brine. These Cl-rich high salinity brines promoted metasomatism, fluid-assisted deformation and dissolution-reprecipitation processes, as documented by channelway microstructures, healed microfractures and compositional changes in quartz revealed by the cathodoluminescence microscopy. Basement fabrics probably represented effective pathways for fluid flow, which promoted retrograde mineral reactions.

Ferropyrosmalite-bearing inclusions represent the fluids originated from post-peak metamorphic Mesozoic magmatism, most likely of Jurassic age, represented by widespread granitoids intruding the basement. However, Cretaceous and Cenozoic tectonomagmatic processes cannot be ruled out as triggers of hydrothermal processes, at least to some extent. All these fluids were associated with regional metasomatism related to retrograde high- to medium-temperature and low-pressure tectonothermal events, which largely overprinted the metamorphic basement of the northern Patagonia.

\section{Acknowledgements}


This is the peer-reviewed, final accepted version for American Mineralogist, published by the Mineralogical Society of America. The published version is subject to change. Cite as Authors (Year) Title. American Mineralogist, in press.

DOI: https://doi.org/10.2138/am-2021-7525. http://www.minsocam.org/

501

502

503

504

505

506

507

508

509

510

511

512

513

514

515

516

517

518

519

520

521

522

523

524

525

526

527

528

529

530

531

532

533

534

Sebastián Oriolo acknowledges financial support of the National Geographic Society (grant CP-123R17) and Agencia Nacional de Promoción Científica y Tecnológica (PICT-20171092). The reviews and constructive comments made by Peter Koděra (Comenius University Bratislava, Slovak Republic) and David Jenkins (Binghamton University, New York, USA) are highly acknowledged. The authors also thank Burkhard Schmidt for his assistance during Raman analysis.

Altree-Williams, A., Pring, A., Ngothai, Y., and Brugger, J. (2015) Textural and compositional complexities resulting from coupled dissolution-reprecipitation reactions in geomaterials. Earth-Science Reviews, 150, 628-651.

Apopei, A.I., and Buzgar, N. (2010) The Raman study of amphiboles. Analele Ştiinţifice de Universităţii Al. I. Cuza Iaşi Geologie, 56, 57-83.

Aragón, E., Castro, A., Díaz-Alvarado, J., and Liu, D.-Y. (2011) The North Patagonian batholith at Paso Puyehue (Argentina-Chile). SHRIMP ages and compositional features. Journal of South American Earth Sciences, 32, 547-554.

Assarsson, G.O. (1950) The quaternary system $\mathrm{CaCl}_{2}-\mathrm{KCl}-\mathrm{NaCl}-\mathrm{H}_{2} \mathrm{O}$. Journal of the American Chemical Society, 72, 1433-1436.

Bakker, R.J. (2017) Re-equilibration processes in fluid inclusion assemblages. Minerals, 7, 117.

Banaszak, M. (2014) Differentiation regimes in the Central Andean magma systems: case studies of Taapaca and Parinacota volcanoes, Northern Chile, 238 p. Ph.D. thesis, University of Göttingen, Göttingen.

Bechis, F., Encinas, A., Concheyro, A., Litvak, V.D., Aguirre-Urreta, B., and Ramos, V.A. (2014) New age constraints for the Cenozoic marine transgressions of northwestern Patagonia, Argentina ( $\left.41^{\circ}-43^{\circ} \mathrm{S}\right)$ : Paleogeographic and tectonic implications. Journal of South American Earth Sciences, 52, 72-93.

Behr, H.-J., and Frentzel-Beyme, K. (1987) Permeability and paleoporosity in crystalline bedrocks of the Central European Basement - Studies of cathodoluminescence. In H.J. Behr and C.B. Raleigh, C.B., Eds., Exploration of the deep continental crust, 2, p. 477-497. Springer, Berlin Heidelberg New York.

Bodnar, R.J. (2003) Introduction to aqueous electrolyte fluid inclusions. In I. Samson, A. Anderson, D. Marshall, Eds., Fluid inclusions: Analysis and interpretation, 32, p. 81-100. Mineralogical Association of Canada, Vancouver. 
This is the peer-reviewed, final accepted version for American Mineralogist, published by the Mineralogical Society of America. The published version is subject to change. Cite as Authors (Year) Title. American Mineralogist, in press. DOI: https://doi.org/10.2138/am-2021-7525. http://www.minsocam.org/

Borrok, D.M., Kelser, S.E., Boer, R.H., and Essene, E.J. (1998) The Vergenoeg magnetitefluorite deposit, South Africa: Support for a hydrothermal model for massive iron oxide deposits. Economic Geology, 93, 564-586.

Budzyń, B., Harlov, D.E., Williams, M.L., and Jercinovic, M.J. (2011) Experimental determination of stability relations between monazite, fluorapatite, allanite, and REEepidote as a function of pressure, temperature, and fluid composition. American Mineralogist, 96, 1547-1567.

Burke, E.A.J. (2001) Raman microspectrometry of fluid inclusions. Lithos, 55, 139-158.

Castro, A., Moreno-Ventas, I., Fernández, C., Vujovich, G., Gallastegui, G., Heredia, N., Martino, R.D., Becchio, R., Corretgé, L.G., Díaz-Alvarado, J., Such, P., García-Arias, M., and Liu, D.-Y. (2011a) Petrology and SHRIMP U-Pb zircon geochronology of Cordilleran granitoids of the Bariloche area, Argentina. Journal of South American Earth Sciences, 32, 508-530.

Castro, A., Aragón, E., Díaz-Alvarado, J., Blanco, I., García-Casco, A., Vogt, K., and Liu, D.-Y. (2011b) Age and composition of granulite xenoliths from Paso de Indios, Chubut province, Argentina. Journal of South American Earth Sciences, 32, 567-574.

Cepedal, A., Fuertes-Fuente, M., Martín-Izard, A., and Boiron, M.-C. (2003). Fluid composition in Ortosa Au-skarn and El Valle-Boinás Cu-Au skarn, Río Narcea Gold Belt (Spain). Acta Mineralogica-Petrographica, 2, 36-37.

Dalla Salda, L.H., Cingolani, C.A., and Varela, R. (1991) El basamento cristalino de la región norpatagónica de los lagos Gutiérrez, Mascardi y Guillelmo, provincia de Río Negro. Revista de la Asociación Geológica Argentina, 46, 263-276.

Dong, G., and Pollard, P.J. (1997) Identification of ferropyrosmalite by Laser Raman microprobe in fluid inclusions from metalliferous deposits in the Cloncurry District, NW Queensland, Australia. Mineralogical Magazine, 61, 291-293.

Fall, A., Tattitch, B., Bodnar, R.J. (2011) Combined microthermometric and Raman spectroscopic technique to determine the salinity of $\mathrm{H} 2 \mathrm{O}-\mathrm{CO} 2-\mathrm{NaCl}$ fluid inclusions based on clathrate melting. Geochimica et Cosmochimica Acta, 75, 951-964.

Fornero, E., Allegrina, M., Rinaudo, C., Mazziotti-Tagliani, S., Gianfagna, A. (2008). Micro-Raman spectroscopy applied on oriented crystals of fluoro-edenite amphibole. Periodico di Mineralogia, 77, 5-14.

Frezzotti, M.L., Tecce, F., and Casagli, A. (2012) Raman spectroscopy for fluid inclusion analysis. Journal of Geochemical Exploration, 112, 1-20.

García-Sansegundo, J., Farías, P., Gallastegui, G., Giacosa, R.E., and Heredia, N. (2009) Structure and metamorphism of the Gondwanan basement in the Bariloche region (North Patagonian Argentine Andes). International Journal of Earth Sciences, 98, 1599-1608. 
This is the peer-reviewed, final accepted version for American Mineralogist, published by the Mineralogical Society of America. The published version is subject to change. Cite as Authors (Year) Title. American Mineralogist, in press. DOI: https://doi.org/10.2138/am-2021-7525. http://www.minsocam.org/

571

572

573

574

575

576

577

578

579

580

581

582

583

584

585

586

587

588

589

590

591

592

593

594

595

596

597

598

599

600

601

602

603

604

605

606
Giacosa, R., Heredia, N., Césari, O., and Zubia, M. (2001) Hoja 4172-IV, San Carlos de Bariloche (provincias de Río Negro y Bariloche), 77 p. Instituto de Geología y Recursos Minerales (IGRM) - SEGEMAR, Buenos Aires.

Giesting, P.A., Filiberto, J. (2016). The formation environment of potassic-chlorohastingsite in the nakhlites MIL 03346 and pairs and NWA 5790: Insights from terrestrial chloro-amphibole. Meteoritics \& Planetary Science, 51, 2127-2153.

González Díaz, E.F. (1982) Chronological zonation of granitic plutonism in the Northern Patagonian Andes of Argentina: the migration of intrusive cycles. Earth-Science Reviews, $18,365-393$.

Hanley, J.J., and Mungall, J.E. (2003) Chlorine enrichment and hydrous alteration of the Sudbury breccia hosting footwall Cu-Ni-PGE mineralization at the Fraser mine, Sudbury, Ontario, Canada. The Canadian Mineralogist, 41, 857-881.

Harlov, D., and Austrheim, H. (2012) Metasomatism and the chemical transformation of rock: The role of fluids in terrestrial and extraterrestrial processes, 806 p. Springer, Berlin Heidelberg.

Harlov, D.E., Wirth, R., and Hetherington, C.J. (2011) Fluid-mediated partial alteration of monazite: The role of coupled dissolution-reprecipitation during apparent solid state element mass transfer. Contributions to Mineralogy and Petrology, 162, 329-348.

Jamtveit, B., Austrheim, H., and Malthe-Sørenssen, A. (2000) Accelerated hydration of the Earth's deep crust induced by stress perturbations. Nature, 408, 75-78.

Jenkins, D.M. (2019). The incorporation of chlorine into calcium amphibole. American Mineralogist, 104, 514-524.

Koděra, P., Rankin, A.H., and Lexa, J. (1998) Evolution of fluids responsible for iron skarn mineralisation: An example from the Vyhne-Klokoč deposit, Western Carpathians, Slovakia. Mineralogy and Petrology, 64, 119-147.

Koděra, P., Murphy, P.J., and Rankin, A.H. (2003) Retrograde mineral reactions in saline fluid inclusions: The transformation ferropyrosmalite $\leftrightarrow$ clinopyroxene. American Mineralogist, 88, 151-158.

Kwak, T.A.P. (1986) Fluid inclusions in skarns (carbonate replacement deposits). Journal of Metamorphic Geology, 4, 363-384.

Lafuente B., Downs R. T., Yang H., and Stone N. (2015) The power of databases: the RRUFF project. In: Highlights in Mineralogical Crystallography, T. Armbruster and R. M. Danisi, eds. Berlin, Germany, W. De Gruyter, pp 1-30

Leissner L., Schlüter, J., Horn, I., and Mihailova B. (2015) Exploring the potential of Raman spectroscopy for crystallochemical analyses of complex hydrous silicates: I. Amphiboles. American Mineralogist, 100, 2682-2694. 
Li, C., and Naldrett, A.J. (1993) High chlorine alteration minerals and calcium-rich brines in fluid inclusions from the Strathcona deep copper zone, Sudbury, Ontario. Economic Geology, 88, 1780-1796.

Martínez, J.C., Dristas, J.A., and Massonne, H.-J. (2012) Palaeozoic accretion of the microcontinent Chilenia, North Patagonian Andes: high-pressure metamorphism and subsequent thermal relaxation. International Geology Review, 54, 472-490.

Martínez Dopico, C.I., Tohver, E., López de Luchi, M.G., Wemmer, K., Rapalini, A.E., and Cawood, P.A. (2017). Jurassic cooling ages in Paleozoic to early Mesozoic granitoids of northeastern Patagonia: ${ }^{40} \mathrm{Ar} /{ }^{39} \mathrm{Ar},{ }^{40} \mathrm{~K}-{ }^{40} \mathrm{Ar}$ mica and $\mathrm{U}-\mathrm{Pb}$ zircon evidence. International Journal of Earth Sciences, 106, 2343-2357.

Matthews, A.N. (1976) Magnetite formation by the reduction of hematite with iron under hydrothermal conditions. American Mineralogist, 61, 927-932.

Neuser, R.D., Bruhn, F., Götze, J., Habermann, D. and Richter, D.K. (1995) Cathodoluminescence: method and application. Zentralblatt für Geologie und Paläontologie, 1-2, 287-306.

Oakes, C.S., Bodnar, R.J., and Simonson, J.M. (1990) The system NaCl-CaCl2-H2O: I. The ice liquidus at $1 \mathrm{~atm}$ total pressure. Geochimica et Cosmochimica Acta, 54, 603-610.

Olaizola, E.R., Bechis, F., Ballesteros, J., Oriolo, S., Christie Newbery, J., and Yagupsky, D.L. (2020) Análisis de la evolución cinemática y exhumación asociadas a las fases de deformación registradas en los Andes Norpatagónicos a los 4150’ S. XXI Congreso Geológico Argentino, Puerto Madryn.

Oriolo, S., Schulz, B., González, P. D., Bechis, F., Olaizola, E., Krause, J., Renda, E., and Vizán, H. (2019) The Late Paleozoic tectonometamorphic evolution of Patagonia revisited: Insights from the pressure-temperature-deformation-time (P-T-D-t) path of the Gondwanide basement of the North Patagonian Cordillera (Argentina). Tectonics, 38, 2378-2400. https://doi.org/10.1029/2018TC005358

Orts, D.L., Folguera, A., Encinas, A., Ramos, M., Tobal, J., and Ramos, V.A. (2012) Tectonic development of the North Patagonian Andes and their related Miocene foreland basin $\left(41^{\circ} 30^{\prime}-43^{\circ} \mathrm{S}\right)$. Tectonics, 31 , TC3012.

Páez, G.N., Ruiz, R., Guido, D.M., Jovic, S.M., and Schalamuk, I.B. (2010) The effects of K-metasomatism in the Bahía Laura Volcanic Complex, Deseado Massif, Argentina: Petrologic and metallogenic consequences. Chemical Geology, 273, 300-313.

Pan, Y., Fleet, M.E., Barnett, R.L., and Chen, Y. (1993) Pyrosmalite in Canadian Precambrian sulfide deposits; mineral chemistry, petrogenesis and significance. The Canadian Mineralogist, 31, 695-710.

Putnis, A. (2009) Mineral replacement reactions. Reviews in Mineralogy and Geochemistry, 70, 87-124. 
This is the peer-reviewed, final accepted version for American Mineralogist, published by the Mineralogical Society of America. The published version is subject to change. Cite as Authors (Year) Title. American Mineralogist, in press. DOI: https://doi.org/10.2138/am-2021-7525. http://www.minsocam.org/

Putnis, A., and Austrheim, H. (2010) Fluid-induced processes: metasomatism and metamorphism. Geofluids, 10, 254-269.

Putnis, A., and John, T. (2010) Replacement processes in the Earth's crust. Elements, 6, 159-164.

Raič, S., Mogessie, A., Krenn, K., Hauzenberger, C.A., and Tropper, P. (2018) Deciphering Magmatic and Metasomatic Processes Recorded by Fluid Inclusions and Apatite within the $\mathrm{Cu}-\mathrm{Ni} \pm \mathrm{PGE}-$ Sulfide Mineralized Bathtub Intrusion of the Duluth Complex, NE Minnesota, USA. Journal of Petrology, 59, 1167-1192.

Rapela, C.W., Spalletti, L.A., Merodio, J.C., and Aragón, E. (1988) Temporal evolution and spatial variation of early Tertiary volcanism in the Patagonian Andes $\left(40^{\circ} \mathrm{S}-42^{\circ} 30^{\prime} \mathrm{S}\right)$. Journal of South American Earth Sciences, 1, 75-88.

Rebay, G., Riccardi, M.P., Spalla, M.I. (2015) Fluid rock interactions as recorded by Clrich amphiboles from continental and oceanic crust of Italian orogenic belts. Periodico di Mineralogia, 84, 751-777.

Renda, E.M., Alvarez, D., Prezzi, C., Oriolo, S., and Vizán, H. (2019) Inherited basement structures and their influence in foreland evolution: A case study in Central Patagonia, Argentina. Tectonophysics, 772, 228232.

Roedder, E. (1962) Ancient fluids in crystals. Scientific American, 207, 38-47.

Rösche, C. (2018) Thermal stability and oxidation processes in amphiboles on the tremolite-ferro-actinolite join studied by Raman spectroscopy. BSc. Thesis, University of Hamburg.

Ruiz-Agudo, E., Putnis, C.V., and Putnis, A. (2014) Coupled dissolution and precipitation at mineral-fluid interfaces. Chemical Geology, 383, 132-146.

Steele-MacInnis, M., Bodnar, R.J. and Naden, J. (2011) Numerical model to determine the composition of $\mathrm{H}_{2} \mathrm{O}-\mathrm{NaCl}-\mathrm{CaCl}_{2}$ fluid inclusions based on microthermometric and microanalytical data. Geochimica et Cosmochimica Acta, 75, 21-40.

Suárez, R.J., and González, P.D. (2018) Caracterización geológica del metamorfismo diastatermal mesozoico en la Cuenca Neuquina y su relación con la anomalía térmica en el sinrift. Revista de la Asociación Geológica Argentina, 75, 457-472.

Tazava, E., Oliveira, C.G., and Souza Gomes, N. (1999) Ocorrência de ferropirosmalita nas brechas mineralizadas do depósito de $\mathrm{Au}-\mathrm{Cu}-( \pm \mathrm{ETR}-\mathrm{U})$ de Igarapé Bahia, província mineral de Carajás. Revista Brasileira de Geociências, 29, 345-348.

Touret, J.L.R. (2001) Fluids in metamorphic rocks. Lithos, 55, 1-25.

Van den Kerkhof, A.M., and Hein, U.F. (2001) Fluid inclusion petrography. Lithos, 55, 2747. 
This is the peer-reviewed, final accepted version for American Mineralogist, published by the Mineralogical Society of America. The published version is subject to change. Cite as Authors (Year) Title. American Mineralogist, in press. DOI: https://doi.org/10.2138/am-2021-7525. http://www.minsocam.org/

Van den Kerkhof, A.M., Riganti, A., Scherer, T., Kronz, A., and Simon K. (2004) Origin and evolution of Archean quartzites from the Nondweni greenstone belt (South Africa): inferences from a multidisciplinary study. South African Journal of Geology, 107, 559-576.

Van den Kerkhof, A., Kronz, A., and Simon, K. (2014) Deciphering fluid inclusions in high-grade rocks. Geoscience Frontiers, 5, 683-695.

Vaughan, J.P. (1986) The iron end-member of the pyrosmalite series from the Pegmont lead-zinc deposit, Queensland. Mineralogical Magazine, 50, 527-531.

Vityk, M.O., and Bodnar, R.J. (1995) Do fluid inclusions in high-grade metamorphic terranes preserve peak metamorphic density during retrograde decompression? American Mineralogist, 80, 641-644.

Volfinger, M., Robert, J.-L., Vielzeuf, D., Neiva, A.M.R. (1985) Structural control of the chlorine content of $\mathrm{OH}$-bearing silicates (micas and amphiboles). Geochimica et Cosmochimica Acta, 49, 37-48.

Wagner, T., Fusswinkel, T., Wälle, M., and Heinrich, C.A. (2016) Microanalysis of fluid inclusions in crustal hydrothermal systems using laser ablation methods. Elements, 12, 323328.

Wanhainen C., Broman C., Martinsson O., and Magnor B. (2012) Modification of a Palaeoproterozoic porphyry-like system: Integration of structural, geochemical, petrographic, and fluid inclusion data from the Aitik $\mathrm{Cu}-\mathrm{Au}-\mathrm{Ag}$ deposit, northern Sweden. Ore Geology Reviews, 48, 306-331.

Williams, M.L., Jercinovic, M.J., Harlov, D.E., Budzyń, B., and Hetherington, C.J. (2011) Resetting monazite ages during fluid-related alteration. Chemical Geology, 283, 218-225.

Yang, H., Downs, R.T., Yang, Y.W., and Allen, W.H. (2012) Pyrosmalite-(Fe), $\mathrm{Fe}_{8} \mathrm{Si}_{6} \mathrm{O}_{15}(\mathrm{OH}, \mathrm{Cl})_{10}$. Acta Crystallographica Section E: Structure Reports Online, 68, i7-i8.

Yardley, B.W.D., and Bodnar, R.J. (2014) Fluids in the continental crust. Geochemical Perspectives, 3, 1-127.

Zharikov, V.A., Pertsev, N.N., Rusinov, V.L., Callegari, E., and Fettes, D.J. (2007) Metasomatism and metasomatic rocks, 17 p. Recommendations by the IUGS Subcommission on the Systematics of Metamorphic Rocks, International Union of Geological Sciences (IUGS).

Zwart E.W., and Touret J.L.R. (1994) Melting behaviour and composition of aqueous fluid inclusions in fluorite and calcite: applications within the system $\mathrm{H}_{2} \mathrm{O}-\mathrm{CaCl}_{2}-\mathrm{NaCl}$. European Journal of Mineralogy, 6, 773-786.

\section{Figure captions}


This is the peer-reviewed, final accepted version for American Mineralogist, published by the Mineralogical Society of America. The published version is subject to change. Cite as Authors (Year) Title. American Mineralogist, in press. DOI: https://doi.org/10.2138/am-2021-7525. http://www.minsocam.org/

Fig. 1. Geological map of the study area (modified after González Bonorino 1973; GarcíaSansegundo et al. 2009; Bechis et al. 2014; Oriolo et al. 2019). EPMA Th-U-Pb monazite geochronological data (1: Martínez et al. 2012; 2: Oriolo et al. 2019) are shown.

Fig. 2. a) Quartz segregations parallel to $S_{2}$ metamorphic foliation of paragneisses. b) $F_{2}$ tight folds showing rootless hinges defined by quartz segregations (arrows). c) Retrograde chlorite, white mica and opaque minerals showing shape-preferred orientation parallel to subhorizontal $\mathrm{S}_{2}$ planes (cross-polarized light). d) Randomly oriented aggregates of chlorite, actinolite and white mica cross-cutting subhorizontal $\mathrm{S}_{2}$ planes (cross-polarized light). Act: actinolite, Chl: chlorite, Op: opaque minerals, Wmca: white mica.

Fig. 3. Microphotographs of quartz segregation thin sections in cathodoluminescence (left) and transmitted light (crossed polarizers, right). CL microstructures are indicative of hightemperature (a, b; sample BA 28-18, López hill) and low-temperature alteration (c, sample BA 6-18, Jakob lake). 1 = secondary zoning; 2 = grain boundary alteration; 3 = channelway microstructure showing initial blue $\mathrm{CL} ; 4$ = polyminerallic channelway showing brown CL; $5=$ healed cataclastic microstructures observed for initial (blue) and final (violet and reddish) $\mathrm{CL} ; 6=$ subgrains.

Fig. 4. Microphotographs showing multiphase fluid inclusions from the Lopez hill location. a) Natural, non-heated inclusion containing halite and a hexagonal crystal of ferropyrosmalite; b) Natural, non-heated inclusion containing halite, sylvite, hematite, and ferropyrosmalite; c) Same inclusions as (b) after heating over $570{ }^{\circ} \mathrm{C}$. Dissolution of ferropyrosmalite and hematite favours crystallization of clino-amphibole and magnetite, respectively. Note that, after the reaction, two prismatic amphibole crystals formed in the same inclusion. The Raman spectrum of amphibole is shown in Figure $7 \mathrm{~b}$ (polarized spectra, recording $\mathrm{OH}^{-}$stretching bands); d) Natural, non-heated inclusion containing halite, magnetite and ferropyrosmalite; e) Same inclusion as (d) after heating. The resulting clino-amphibole, identified as chloro-hastingsite, lacks in $\mathrm{OH}^{-}$peaks, suggesting substitution of $\mathrm{OH}^{-}$by $\mathrm{Cl}^{-}$(Fig. 7b, unpolarized spectrum). $\mathrm{Hl}$ : halite, Fp: ferropyrosmalite, V: vapor, L: liquid, Syl: sylvite, Hem: hematite, Amp: amphibole, Mag: magnetite.

Fig. 5. Microthermometric results of fluid inclusions. a) Liquid-vapor homogenization temperatures (V: vapor, L: liquid) for early secondary multiphase and late secondary biphasic inclusions; b) Melting temperatures of daughter crystals in the early secondary multiphase inclusions (halite and ferropyrosmalite); c) Brine salinity and total salinity of early secondary multiphase inclusions and late secondary (L-V and V-L) inclusions.

Fig. 6. Fluid inclusion compositions in the system $\mathrm{H}_{2} \mathrm{O}-\mathrm{NaCl}-\mathrm{CaCl}_{2}$ (modified after Oakes et al. 1990; Zwart and Touret 1994). AA: antarcticite, Hl: halite, HH: hydrohalite. Red squares: early secondary multiphase inclusions (total salinity), red circles: early secondary $\mathrm{L}+\mathrm{V} \pm \mathrm{S}$ multiphase inclusions (brine salinity without halite crystals), blue area: late secondary V-L and L-V inclusions.

Fig. 7. Raman spectra of daughter phases in (a) natural, non-heated inclusions showing spectra for ferropyrosmalite and hematite (inclusion in Fig. 4b), and (b) heated inclusions 
755 showing spectra for clino-amphibole with $\mathrm{OH}^{-}$vibration bands in polarized laser light with 756 orientations parallel and perpendicular to the crystallographic c-axis (inclusion in Fig. 4c) 757 and Cl-bearing clino-amphibole (unpolarized laser light; inclusion in Fig. 4e). Raman peaks 758 for the host quartz are subtracted and not shown here.

760 Table 1. Overview of fluid inclusion data obtained from microthermometry with indication 761 of the relative abundance and number of measured fluid inclusions (n). The phase volume 762 fractions at room temperature are estimated for the liquid (L), solid (S) and vapor (V)

763 phases. Phase transition temperatures are given for the melting of $\mathrm{CO}_{2}\left(\mathrm{~T}_{\mathrm{m}} \mathrm{CO}_{2}\right)$, the 764 eutectic temperature $\left(\mathrm{T}_{\mathrm{e}}\right)$, ice melting $\left(\mathrm{T}_{\mathrm{m}}\right.$ ice $)$, hydrohalite $\left(\mathrm{T}_{\mathrm{m}} \mathrm{HH}\right)$, clathrate melting $(\mathrm{Tm}$ 765 clathrate), liquid-vapor homogenization $\left(\mathrm{T}_{\mathrm{h}} \mathrm{L}-\mathrm{V}\right)$ into the liquid (L) or vapor phase (V), 766 sylvite dissolution ( $\left.\mathrm{T}_{\mathrm{m}} \mathrm{Syl}\right)$, halite dissolution $\left(\mathrm{T}_{\mathrm{m}} \mathrm{HI}\right)$, and ferropyrosmalite dissolution 767 ( $\left.T_{m} F p\right)$. Salinities were calculated from the microthermometry data and the models of 768 Steele-McInnes et al. (2011) and Oakes et al. (1990). Mean values are given in brackets. 


\begin{tabular}{|c|c|c|c|c|c|}
\hline & & \multicolumn{2}{|c|}{ Early secondary inclusions } & \multicolumn{2}{|c|}{ Late secondary inclusions } \\
\hline & & \multicolumn{2}{|c|}{$\mathrm{H}_{2} \mathrm{O}-\mathrm{NaCl}-\mathrm{CaCl}_{2} \pm$ Solids $\pm \mathrm{CO}_{2}$} & \multicolumn{2}{|c|}{$\mathrm{H}_{2} \mathrm{O}-\mathrm{NaCl} \pm \mathrm{CO}_{2} \pm \mathrm{N}_{2} \pm \mathrm{H}_{2} \mathrm{~S}$} \\
\hline & & Multiphase & $\mathbf{L}+\mathrm{V}( \pm \mathrm{S})$ & $L+V( \pm S)$ & $\mathrm{V}+\mathrm{L}( \pm \mathrm{S})$ \\
\hline & & Abundant $(n=39)$ & Rare $(n=3)$ & Abundant $(n=33)$ & Abundant $(n=17)$ \\
\hline \multirow{3}{*}{$\begin{array}{l}\text { Phase volume } \\
\text { fractions }\end{array}$} & $\mathbf{L}$ & $0.10-0.65(0.31)$ & $0.30-0.40$ & $0.70-0.87(0.81)$ & $0.05-0.30(0.14)$ \\
\hline & $\mathrm{S}$ & $0.05-0.70(0.53)$ & $0-0.40$ & $0-0.05$ & $0-0.05$ \\
\hline & $\mathbf{V}$ & $0-0.65(0.16)$ & $0.20-0.70$ & $0.10-0.30(0.19)$ & $0.75-0.95(0.87)$ \\
\hline \multirow{9}{*}{$\begin{array}{c}\text { Phase } \\
\text { transition } \\
\text { temperatures } \\
\left({ }^{\circ} \mathbf{C}\right)\end{array}$} & $\mathrm{T}_{\mathrm{m}} \mathrm{CO}_{2}$ & $-57.5--56.9$ & n.o. & n.o. & n.o. \\
\hline & $\mathbf{T}_{\mathrm{e}}$ & $-56--54$ & ca. -58 & $-21.4--21.0$ & n.o. \\
\hline & $\mathbf{T}_{\mathrm{m}}$ ice & $-46.3--28.1(-36.6)$ & ca. -32 & $-3.2-1.5(-0.7)$ & $-3.2-0$ \\
\hline & $\mathbf{T}_{\mathrm{m}} \mathbf{H H}$ & $-20.4--12.0(-16.5)$ & $-15.9--15.0$ & - & - \\
\hline & $\mathbf{T}_{\mathrm{m}}$ clathrates & n.o. & $(0.2)$ & n.o. & n.o. \\
\hline & $\mathbf{T}_{\mathrm{h}} \mathbf{L}-\mathrm{V}$ & $256-515 \mathrm{~L}(381)$ & $251 \mathrm{~L}->350 \mathrm{~V}$ & $254-384$ L (296) & $319-389 \mathrm{~V}(361)$ \\
\hline & $\mathbf{T}_{\mathrm{m}} \mathrm{Syl}$ & ca. 190 & - & - & - \\
\hline & $\mathbf{T}_{\mathrm{m}} \mathbf{H I}$ & $287-556(489)$ & - & - & - \\
\hline & $\mathbf{T}_{\mathrm{m}} \mathbf{F p}$ & $550-581(560)$ & - & - & - \\
\hline \multirow{3}{*}{$\begin{array}{c}\text { Calculated } \\
\text { salinity } \\
\text { (wt. \%) } \\
\end{array}$} & Total salinity & $27-73$ & $27-30$ & $0-5$ & $0-5$ \\
\hline & $\mathrm{NaCl} \pm \mathrm{KCl}$ & $4-64$ & $8-11$ & $0-5$ & $0-5$ \\
\hline & $\mathrm{CaCl}_{2}$ & $10-26$ & $15-20$ & - & - \\
\hline
\end{tabular}


$71^{\circ} 25^{\prime} \mathrm{W}$

c
g
$\vdots$
$\dot{8}$

\section{$+++1+$}
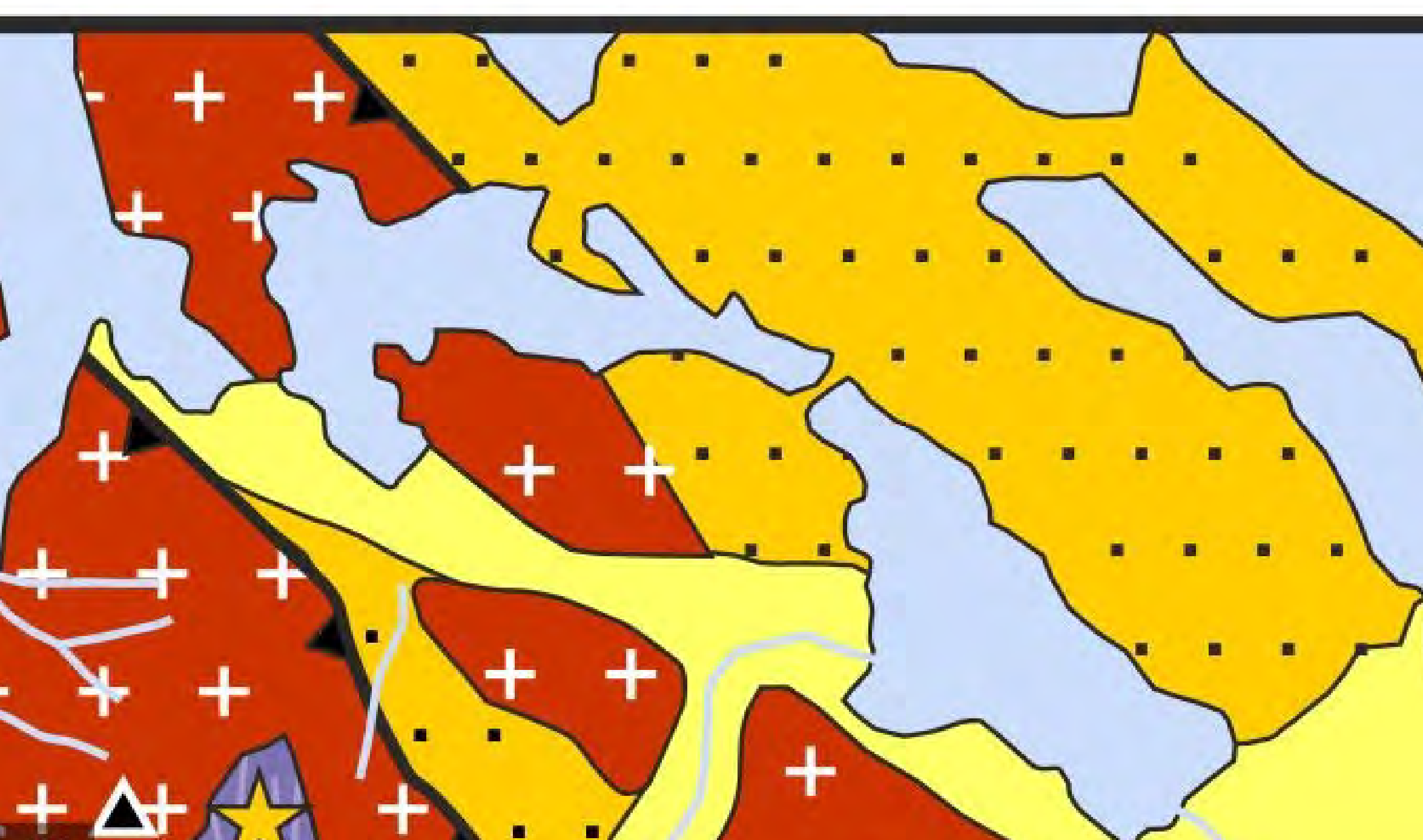

López hill $+\Delta$

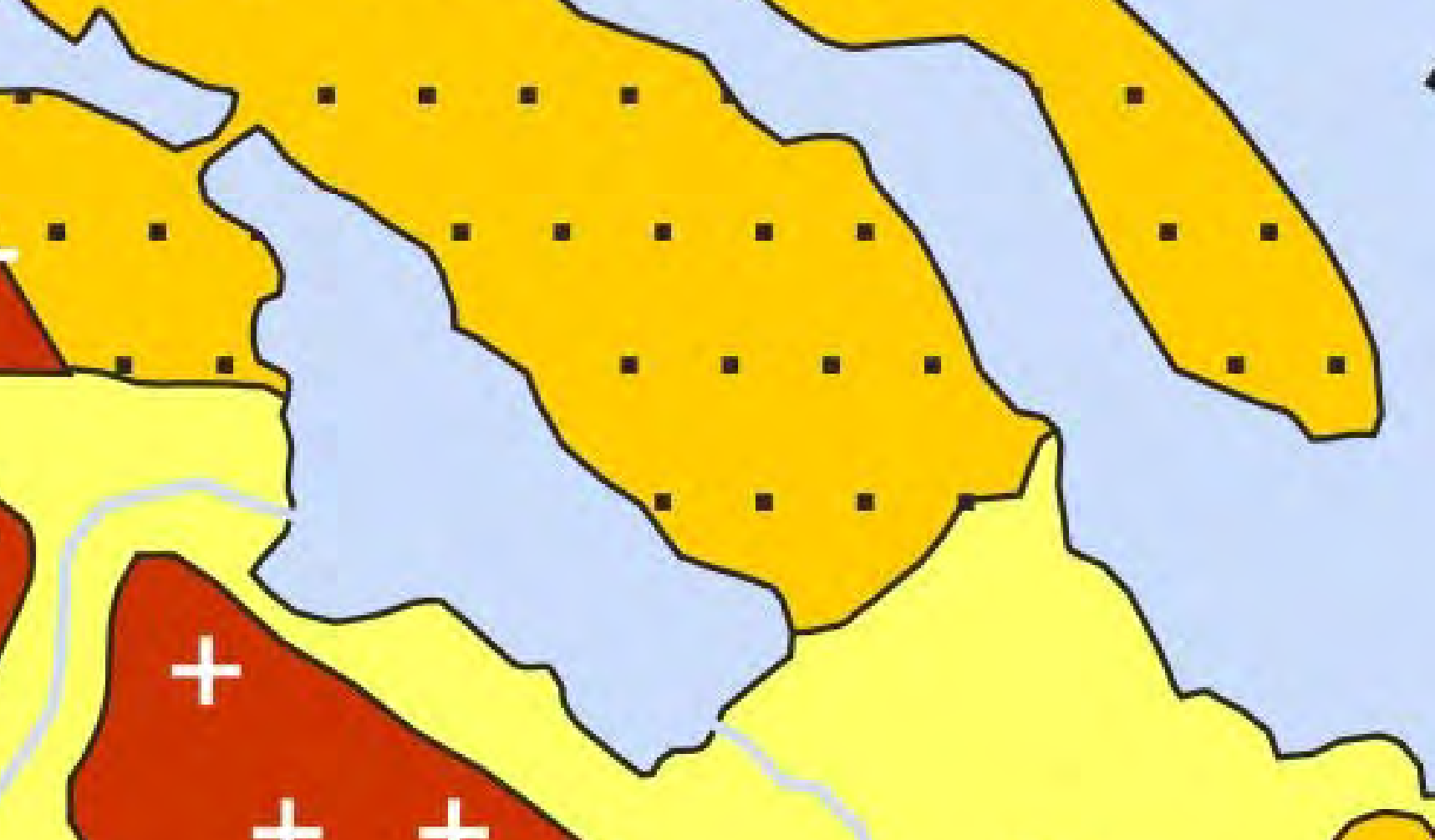

$V$
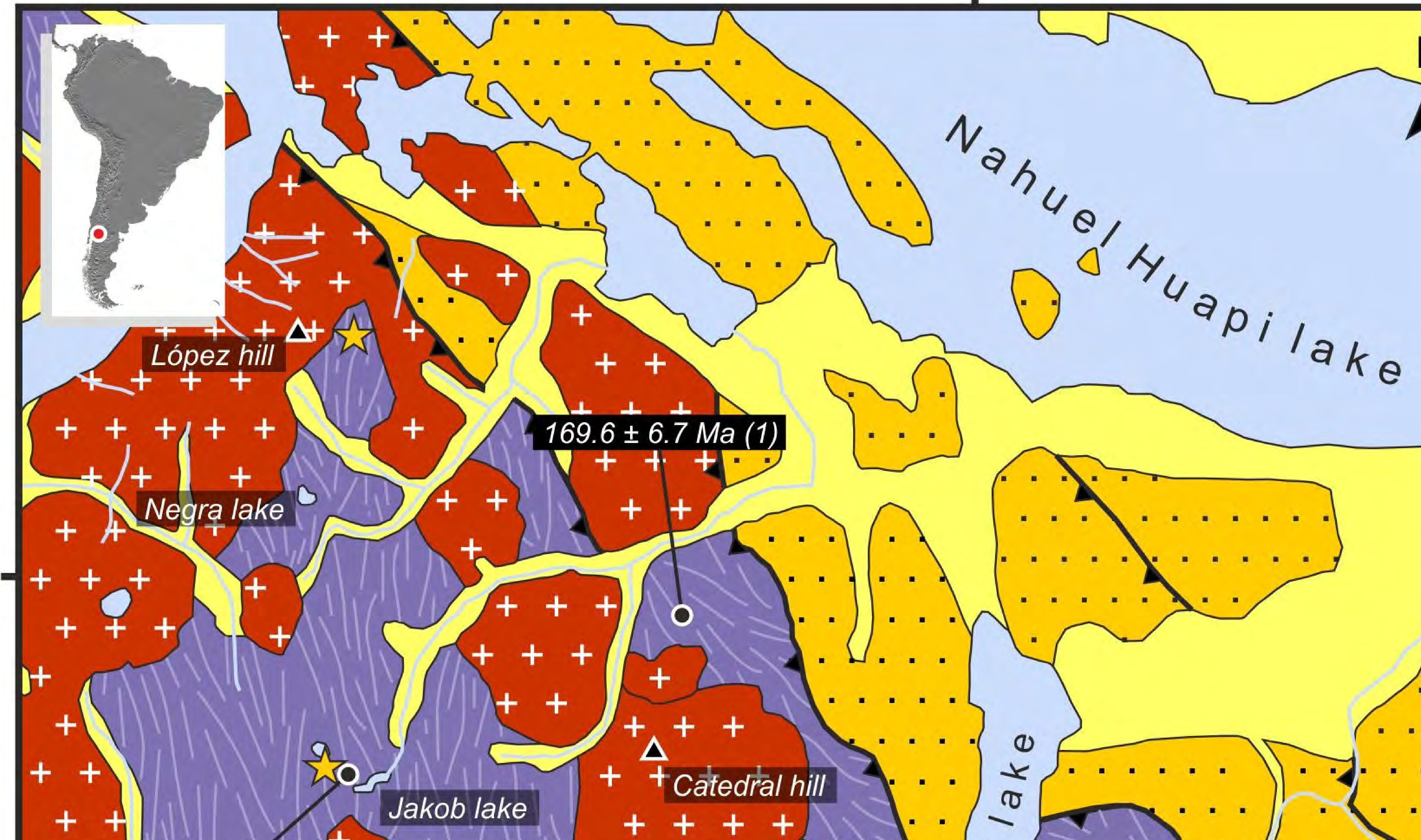

$169.6 \pm 6.7 \mathrm{Ma}(1)$
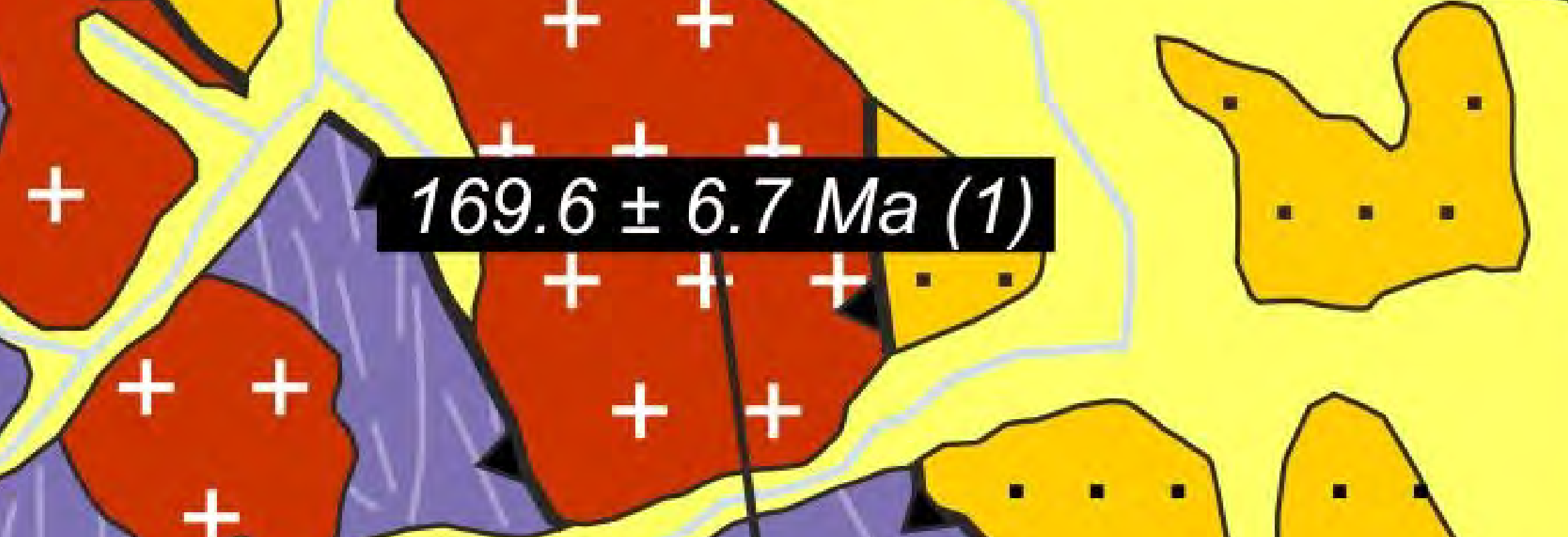


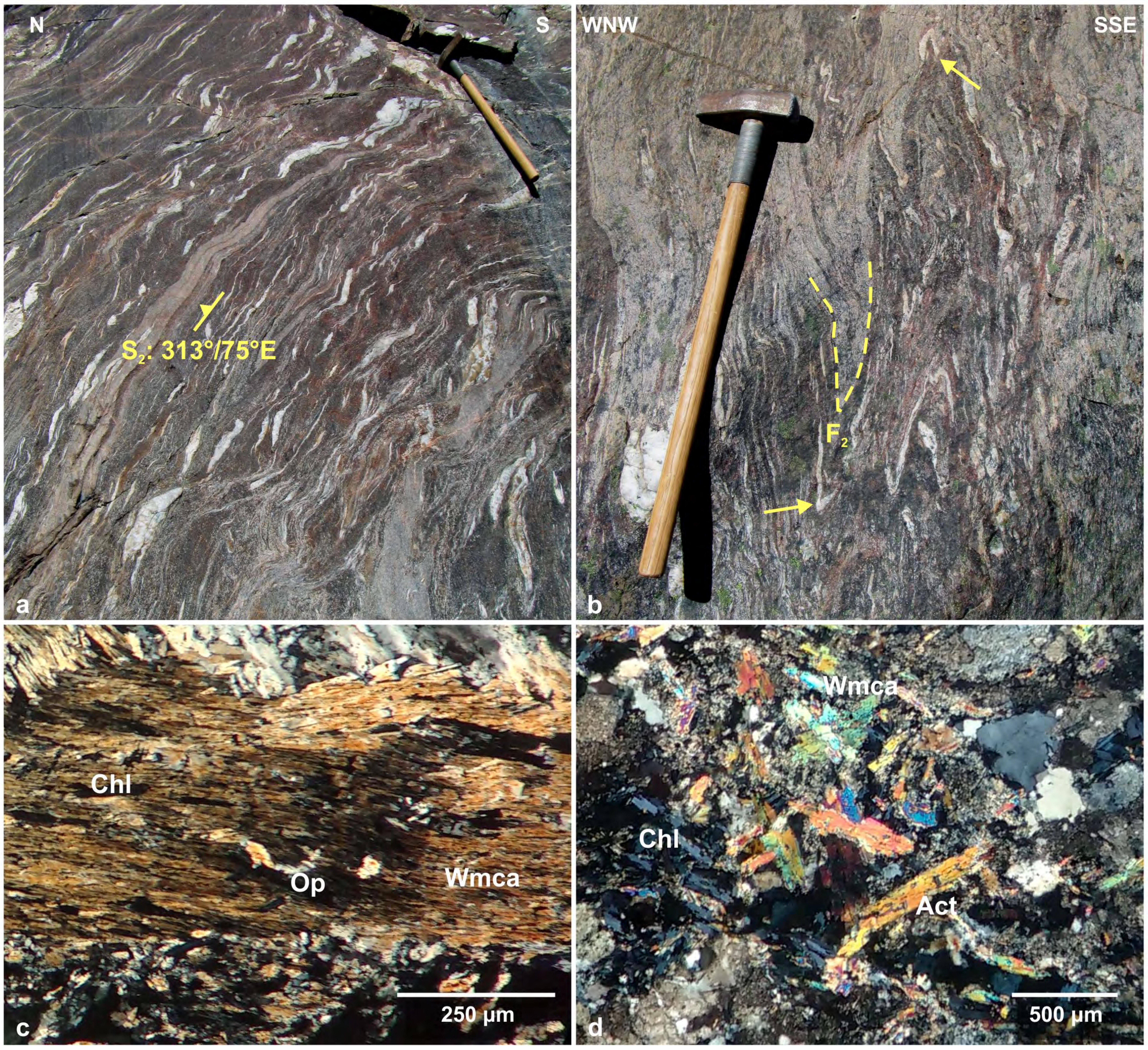




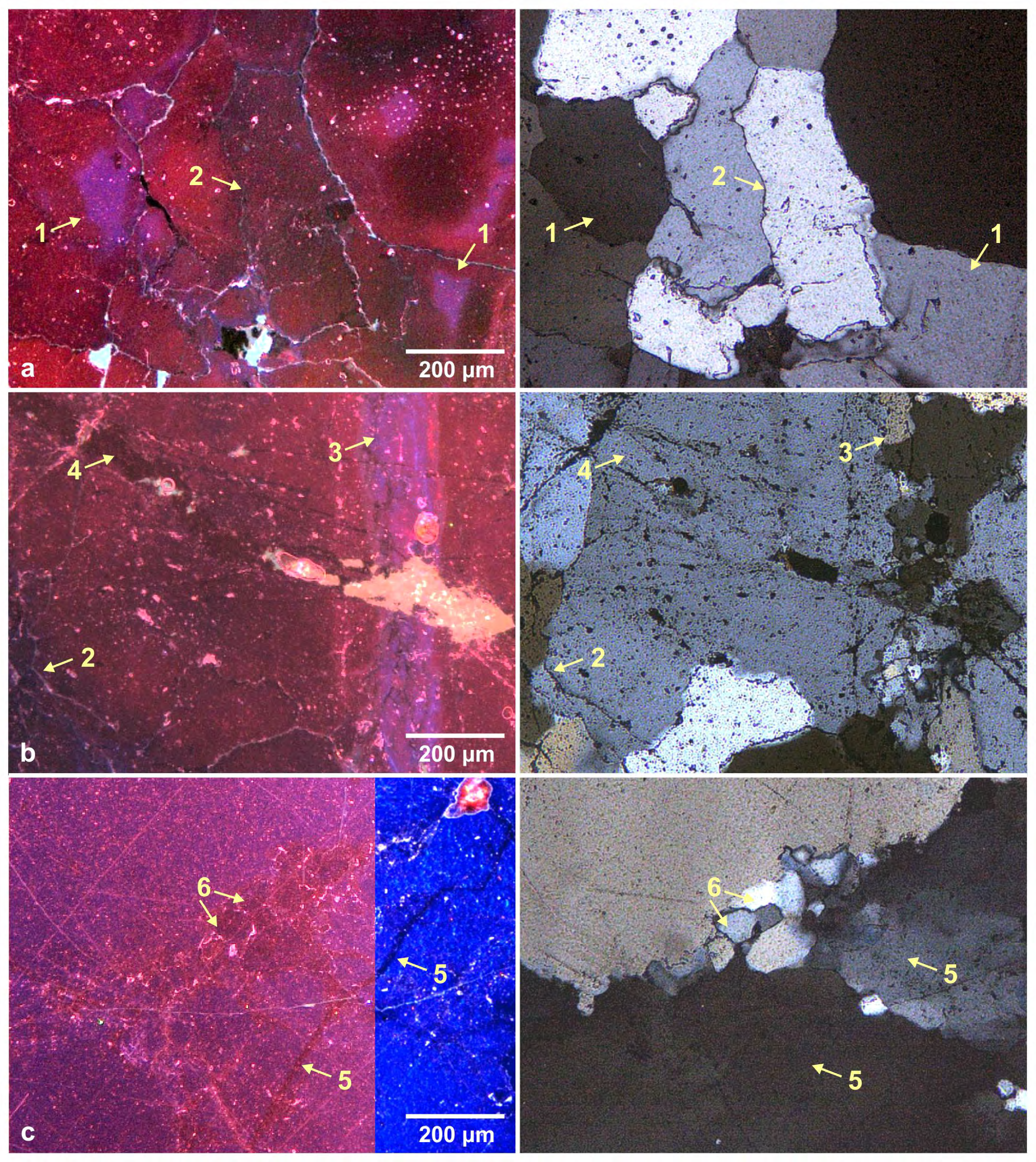




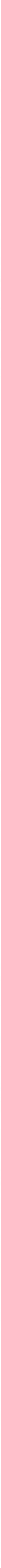




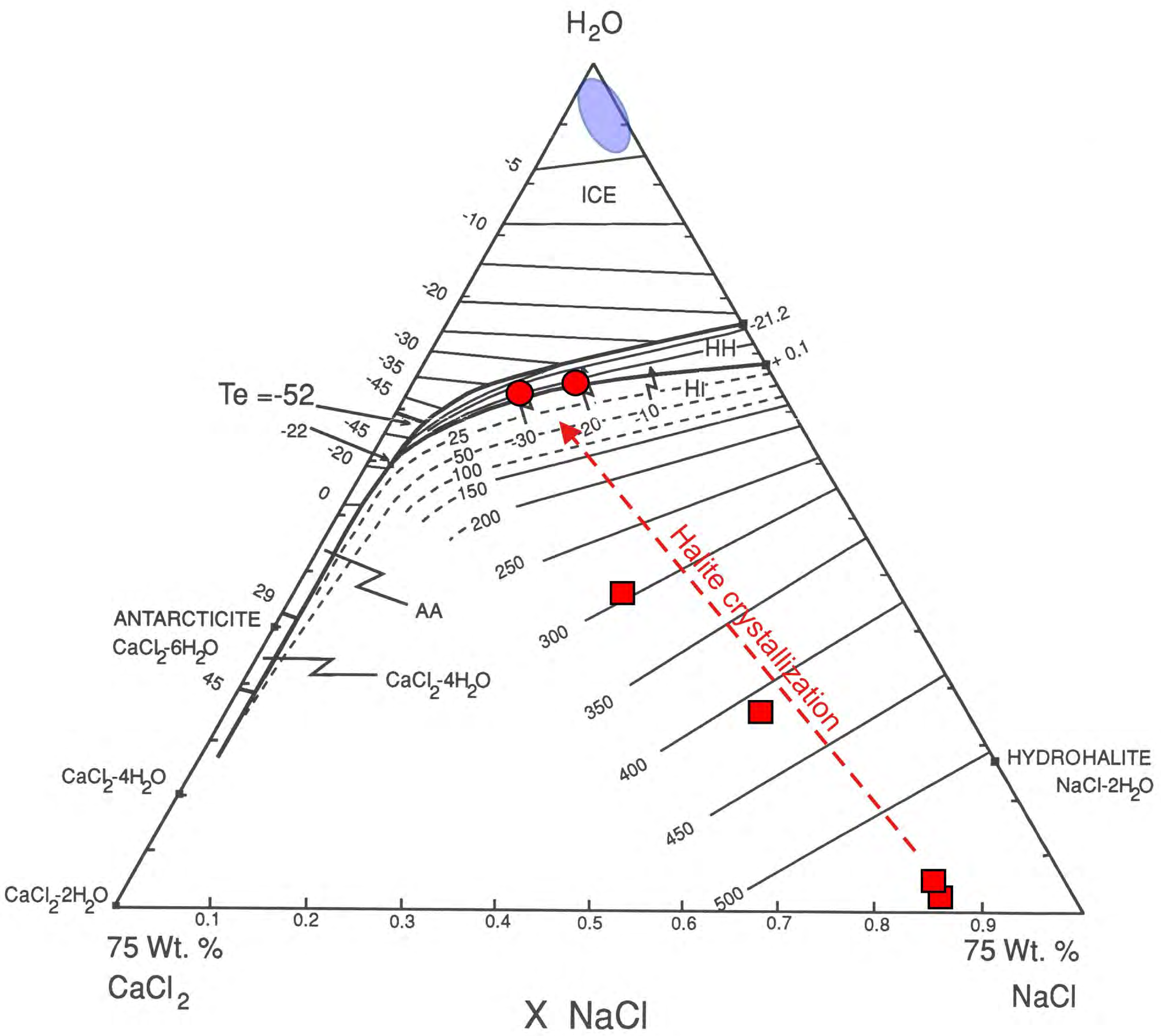




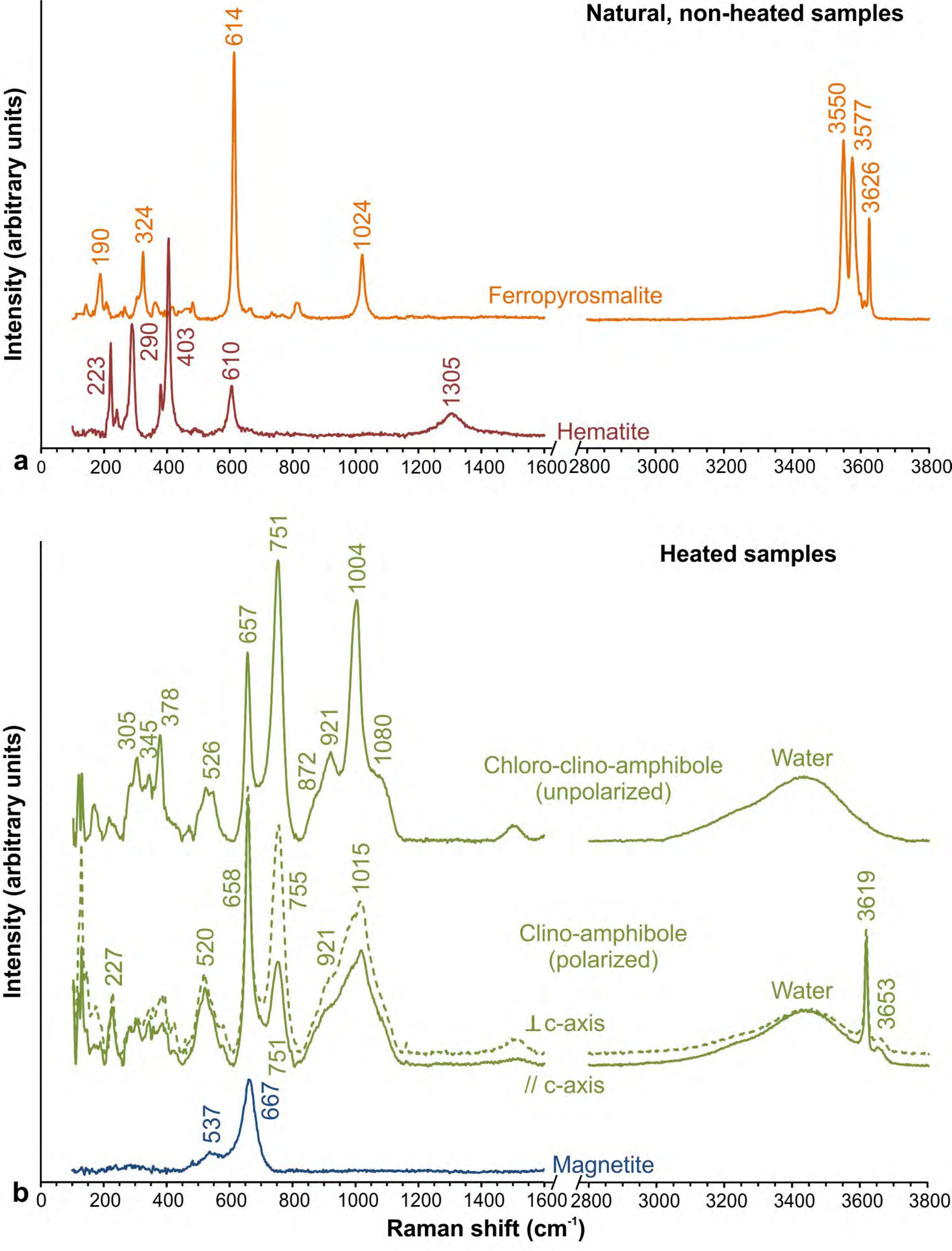

